\title{
Committee to Defend Reproductive Rights v. Myers: Abortion Funding Restrictions as an Unconstitutional Condition
}

Over the last decade abortion has been one of the most controversial issues in American life. In Committee to Defend Reproductive Rights v. Myers (CDRR), ${ }^{1}$ the abortion funding issue reached the California Supreine Court. The court faced a challenge to provisions im California's 1980 Budget $\mathrm{Act}^{2}$ that severely restricted the funding of abortions in the Medi-Cal program, the state medical services program for indigents. ${ }^{3}$ Analyzing the selective funding of a constitutional right in a general benefit program as an unconstitutional condition, the court held that the abortion funding restrictions in the Medi-Cal program, which resulted in the funding of childbirth but not abortion, infringed the woinan's exercise of her right of procreative choice. The court then applied a special standard of review for conditioned benefit programs, ${ }^{4}$ and lield that the asserted state interests were not sufficient to justify the infringeinent. Thus, the court struck down the abortion funding restrictions.

This Note proceeds as follows. Part I summarizes the $C D R R$ facts

1. 29 Cal. 3d 252, 625 P.2d 779, 172 Cal. Rptr. 866 (1981). The six participating justices produced three separate opinions. Justice Tobriner authored the plurality opinion, which was joined by Justices Mosk and Newman. Chief Justice Bird concurred in the judgment and agreed with the plurality that the abortion funding restrictions infringed the fundamental constitutional right of procreative choice. Id. at 288, 625 P.2d at 800-01, 172 Cal. Rptr. at 887-88 (Bird, C.J., concurring). She disagreed, however, with the standard of review used by the plurality and argued for a strict scrutiny standard. Id. at $289 \&$ n.2, 625 P.2d at 801 \& n.2, 172 Cal. Rptr. at 888 \& n.2. Justice Richardson, joined by Justice Clark, dissented, arguing that the majority's infringement analysis "makes no sense." Id. at 297, 625 P.2d at 807, 172 Cal. Rptr. at 894 (Richardson, J., dissenting).

2. Ch. $510, \S 2$, item $287.5,1980$ Cal. Stat. 1069, 1146-48. Abortion funding restrictions in the 1978 Budget Act, ch. 359, § 2, item 248, 1978 Cal. Stat. 755, 823-25, and the 1979 Budget Act, ch. $259, \& 2$, item 261.5, 1979 Cal. Stat. 576, 644-46 were also before the court. These restrictions essentially limited abortion funding to those cases where pregnancy would endanger the mother's life or cause her severe and longlasting physical health damage, where pregnancy was the result of illegal intercourse, or where abortion was necessary to prevent the birth of severely defcctive infants.

3. The California Medi-Cal program funds "[p]hysician, hospital or clinic outpatient, [and] surgical center" services, as well as "[i]npatient hospital services" for "recipients of public assistance [and] medically indigent aged and other persons." CAL. WELF. \& INST. CODE $\$ \$ 14000$, 14132 (a), (b) (West 1980).

4. The special standard of review was established in Bagley v. Washington Township Hosp. Dist., 65 Cal. 2d 499, 421 P.2d 409, 55 Cal. Rptr. 401 (1966). 
and opinions. Part II outlines prior law on the right of procreative choice and the doctrine of unconstitutional conditions. Part III argues that the court's use of the unconstitutional conditions doctrine has created a far-reaching and unwise rule against the selective funding of constitutional rights. Part IV suggests that a better approach to the abortion funding issue would be to recognize the special importance of the procreative right and require the state to be neutral toward the expressions of the right. Requiring the state to be neutral would lead to the same result reached by the $C D R R$ court, but it would do so because of the special nature of the procreative right and not because of a general rule agamst the selective funding of constitutional rights.

\section{The CASE}

\section{A. The Facts}

Following the United States Supreine Court decision of Maher $v$. $R o e^{5}$, which rejected federal constitutional challenges to state funding restrictions on nontherapeutic abortions, the California Legislature responded by sharply restricting Medi-Cal abortion funding. ${ }^{6}$ In a suit against several state officials, ${ }^{7}$ the $C D R R$ plaintiffs ${ }^{8}$ challenged the restrictions on constitutional and statutory grounds. ${ }^{9}$ The superior court rejected plaintiffs' arguments. ${ }^{10}$ Plaintiffs appealed and a divided court of appeal upheld the abortion funding restrictions against constitu-

5. 432 U.S. 464 (1977).

6. See Budget Act of 1978, ch. 359, \& 2, item 248, 1978 Cal. Stat. 755, 823-25 (expired June $30,1979)$. Plaintiffs and defendants agreed that the restrictions would rednce Medi-Cal reimbursed abortions by approximately $95 \%$. Committee to Defend Reproductive Rights v. Myers, 156 Cal. Rptr. 73, 77 (1st Dist. 1979), (officially depublished pursuant to CAL. CT. R. 976(d) (West 1982)).

The 1978 Budget Act restrictions on abortion expired during the course of the litigation, but similar restrictions were imcluded in the Bndget Acts of 1979 and 1980. See supra note 2. Plaintiffs filed separate suits to enjoin the abortion funding restrictions in each of these acts. CDRR, 29 Cal. 3d at 259-60, 625 P.2d at 782-83, 172 Cal. Rptr. at 869-70. Although the 1979 Budget Act had also expired by the time of the supreme court's decision and thus both the 1978 and 1979 Acts were "technically moot," the court consolidated the three actions since most of the briefs were filed in connection with the 1978 and 1979 Acts. Id. at 260 n.3, 625 P.2d at 783 n.3, 172 Cal. Rptr. at $870 \mathrm{n.3}$.

7. Defendants included Beverlee A. Myers, Director of the State Department of Health Services; Kenneth Cory, State Controller; and Jesse M. Unruh, State Treasurer.

8. Plaintiffs included organizations active in welfare, health care, and women's rights; three physicians; one patient; and one taxpayer.

9. Implementation of the restrictions was stayed during the course of the hitigation. The superior court granted a temporary restraining order. Committee to Defend Reproductive Rights v. Myers, No. 74170 (San Francisco Super. Ct. Aug. 7, 1978). The court of appeal and the supreme court, in turn, granted writs of supersedeas, staying the dissolution of the temporary restraining order until they could rule on the case.

10. 29 Cal. $3 d$ at 259,625 P.2d at 782,172 Cal. Rptr. at 869 . 
tional challenge but invalidated them to the extent they were more restrictive than the abortion funding restrictions in the federal Medicaid prograin. ${ }^{11}$ On plaintiffs' petition, the California Supreme Court granted a hearing.

\section{B. The Opinions}

Writimg for the plurality, Justice Tobriner first addressed the issue of whether the court was required to follow the United States Supreme Court's nost recent abortion funding decision of Harris v. McRae, ${ }^{12}$ which upheld against constitutional challenge sweeping federal restrictions on Medicaid abortion funding. He observed that the California Constitution is "a document of independent force,"13 and that the California Supreme Court has both the authority and the obligation to exercise independent legal judgment in interpretimg its provisions. Thus, the court was not bound by federal precedent in considering the plaintiffs' claims that the abortion funding restrictions violated the California Constitution. ${ }^{14}$

The court understood the legislative attempt to fund childbirth but not abortion as analogous to previous unconstitutional condition cases. ${ }^{15}$ The conditioned benefit cases stand for the proposition that while the government nuay be under no obligation to offer a benefit, if it does, it cannot nuake the benefit conditional on the nonassertion of a constitutional right. ${ }^{16}$ Similarly, the $C D R R$ court held that while the state was under no obligation to establish a Medi-Cal program, once it

11. 156 Cal. Rptr. 73, 86 (1st Dist. 1979), officially depublished pursuant to CAL. CT. R. 976(d) (West 1982). Abortion funding in the federal Medicaid program was restricted by the Hyde Amendinent. Originally, the Hyde Amendınent prohibited federal funding of abortions except when the pregnant woman's life would be endangered if she carried the fetus to term. See Act of Sept. 30, 1976, Pub. L. No. 94-439, \& 209, 90 Stat. 1434. A later version also provided funding in cases of rape or incest. See, e.g., Joint Resolution of Nov. 20, 1979, Pub. L. No. 96-123, \& 109, 93 Stat. 926.

12. 448 U.S. 297 (1980).

13. $29 \mathrm{Cal}$. 3d at 261,625 P.2d at $783,172 \mathrm{Cal}$. Rptr. at 870.

14. The court has frequently interpreted language in the California Constitution differently than comparable language in the federal Constitution. Compare, e.g., Serrano v. Priest, $18 \mathrm{Cal} .3 \mathrm{~d}$ 728, 557 P.2d 929, 135 Cal. Rptr. 345 (1976) (striking down a school funding scheme that resulted in less money for poorer districts as a violation of equal protection) with Rodriquez v. San Antomio Indep. School Dist., 411 U.S. 1 (1973) (upholding a similar funding scheme).

15. $29 \mathrm{Cal}$. 3d at 263-64, 625 P.2d at 785-86, 172 Cal. Rptr. at 872-73. The Suprcme Court in Maher v. Roe, 432 U.S. 464, 474 (1977), and Harris v. McRae, 448 U.S. 297, 316 (1980), held that the unconstitutional condition cases were distinguishable because the abortion funding restrictions placed no "additional obstacle" in the path of a woman who wanted to exercise her constitutional right of procreative choice. The $C D R R$ court rejected the obstacle analysis as imconsistent with the Califormia unconstitutional condition cases. $29 \mathrm{Cal}$. 3d at 268, 625 P.2d at 788, $172 \mathrm{Cal}$. Rptr. at 875 .

16. $29 \mathrm{Cal} .3 \mathrm{~d}$ at 263,625 P.2d at 785, $172 \mathrm{Cal}$. Rptr. at 872 (citing Danskin v. San Diego Unified School Dist., 28 Cal. 2d 536, 545-46, 171 P.2d 885, 891 (1946)). 
had done so it could not deny benefits solely because a woman chose to exercise her constitutional right of procreative choice by having an abortion. ${ }^{17}$ The court found that the constitutionality of the challenged abortion funding restrictions was controlled by a special rule from these conditioned benefit cases: the selective funding of a constitutional right in a general benefit program is subject to the scrutiny of the three-pronged Bagley v. Washington Township Hospital District ${ }^{18}$ test. $^{19}$

To establish the constitutionality of the abortion funding restrictions under the Bagley test, the state had to deinonstrate: "(1) 'that the imposed conditions relate to the purposes of the legislation which confers the benefit or privilege'; (2) that 'the utility of imposing the conditions ... manifestly outweigh[s] any resulting impairment of constitutional rights'; and (3) that there are no 'less offensive alternatives' available for achieving the state's objective."20

The court found the abortion restrictions deficient on all three counts. First, the restrictions bore no relation to the purposes of the Medi-Cal program. In fact, they impeded its purpose of providing health care to inedically indigent persons. ${ }^{21}$ Second, the funding restrictions would not serve the state's interest in conserving fiscal resources since any money saved by refusing to fund abortions would be spent on maternity care and childbirth expenses and on supporting the children of indigent mothers. ${ }^{22}$ Moreover, the state's expressed interest im protecting a nonviable fetus did not outweigh the wornan's fundamental right of procreative choice. ${ }^{23}$ Third, even if the abortion funding restrictions were characterized as an effort to fund childbirth, they failed the least offensive alternative requirement. ${ }^{24}$ By funding both childbirth and abortion, the state could ineet the childbirth needs of indigent women without burdening their right of procreative choice. Thus, since the state could not meet its burden under the Bagley test, the court held the abortion funding restrictions violated the California Constitution. ${ }^{25}$

17. 29 Cal. 3d at 284-85 \& n.31, 625 P.2d at $798 \&$ n.31, 172 Cal. Rptr. 885 \& n.31. The California Supreme Court first recognized a woman's constitutional right to choose whether or not to bear a child in People v. Belous, 71 Cal. 2d 954, 458 P.2d 194, 80 Cal. Rptr. 354 (1969), four years before a similar right was recognized under the United States Constitution in Roe v. Wade, 410 U.S. 113 (1973).

18. Bagley v. Washington Township Hosp. Dist., 65 Cal. 2d 499, 421 P.2d 409, 55 Cal. Rptr. 401 (1966).

19. CDRR, 29 Cal. 3d at 270,625 P.2d at 789, 172 Cal. Rptr. at 876.

20. Id. at 258, 625 P.2d at 781, 172 Cal. Rptr. at 868 (quoting Bagley, 65 Cal. 2d at 505-07, 421 P.2d at 414-15, 55 Cal. Rptr. at 406-07).

21. 29 Cal. 3d at 271-73, 625 P.2d at 790-91, 172 Cal. Rptr. at 877-78.

22. Id. at 277 \& n.23, 625 P.2d at $794 \&$ n.23, 172 Cal. Rptr. at $881 \&$ n.23.

23. Id. at 273-82, 625 P.2d at 791-97, 172 Cal. Rptr. at 878-84.

24. Id. at 282-83, $625 \mathrm{P} .2 \mathrm{~d}$ at 797-98, $172 \mathrm{Cal}$. Rptr. at 884-85.

25. Id. at 285,625 P.2d at 799,172 Cal. Rptr. at 886 . In a footnote, the court declared that 
Chief Justice Bird concurred. While essentially agreeing with the court's selective funding analysis and the result reached, she rejected the Bagley test as an outdated attempt to formulate a standard of strict scrutiny. She suggested that conditioned benefit programs should be evaluated by a strict scrutimy standard, with the state required to show a compelling interest to justify a restricted benefit. ${ }^{26}$

Justices Richardson and Clark dissented, rejecting as "distorted logic" the majority's view that the funding of childbirth but not of abortion infringed a woman's constitutional rights. ${ }^{27}$ They found the plurahty's analogy to conditioned benefit cases misplaced, since the legislative action in $C D R R$ "imposed no conditions whatever" upon the rights of a potential recipient to the benefits the prograin offered. ${ }^{28}$ They instead would have followed the United States Supreme Court's analysis in Maher v. Roe $e^{29}$ and Harris v. $M c R a e^{30}$ which upheld similar restrictions on abortion funding.

II

LEGAL BACKGROUND

\section{A. The Right of Procreative Choice}

The Califormia Supreme Court first recognized the "fundainental right of the woman to choose whether to bear children" in its 1969 decision in People v. Belous. ${ }^{31}$ Belous declared that a woinan had a constitutional right of procreative choice that "followed from the Supreme Court's and this court's repeated acknowledgeinent of a 'right to privacy' or 'liberty' in matters relating to marriage, family, and

the restrictions were also unconstitutional under equal protection principles. Because of "thc similarity of the applicable principles," however, it saw no need to undertake a separatc analysis. Id. at $276 \mathrm{n} .22,625$ P.2d at $793 \mathrm{n} .22,172 \mathrm{Cal}$. Rptr. at $880 \mathrm{n} .22$.

26. Id. at $289 \& \mathrm{n} .2,625$ P.2d at $801 \& \mathrm{n} .2,172$ Cal. Rptr. at 888 \& n.2 (Bird, C.J., concurring).

27. Id. at 297-98, 625 P.2d at 807, 172 Cal. Rptr. at 894 (Richardson, J., dissenting).

Justice Richardson also suggested that $C D R R$ is an appropriations casc and that only the legislature enjoys the constitutional power to appropriate statc funds. Id. at 305,625 P.2d at 811 12, 172 Cal. Rptr, at 898-99 (Richardson, J., dissenting). As Chicf Justice Bird pointed out, id. at 287 \& n.1, 625 P.2d at 800 \& n.1, 172 Cal. Rptr. at 887 \& n.1 (Bird, C.J., concurring), however, the legislature attached a proviso to the 1980 Budget Act appropriating funds for abortions if the restrictions were held unconstitutional. See Budget Act of 1980, ch. 510, \& 2, itein 287.5, 1980 Cal. Stat. 1072, 1148. Since an appropriation existed to pay for the abortions, the court transgressed no separation of powers doctrine by ordering the state to disregard thc budgetary restrictions. See generally Note, Mandel v. Myers: Judicial Encroachment on Legislative Spending Powers, 70 CALIF. L. REv. 932 (1982).

28. 29 Cal. $3 d$ at 299,625 P.2d at 808,172 Cal. Rptr. at 895 .

29. 432 U.S. 464 (1977).

30. 448 U.S 297 (1980).

31. 71 Cal. 2d 954, 963, 458 P.2d 194, 199-200, 80 Cal. Rptr. 354, 359-60 (1969). 
sex."32 Belous involved a challenge to a criminal statute that made it unlawful to perform an abortion unless it was necessary to preserve a woman's life. Because the statute effectively prohibited an abortion except to prevent the certain death of the mother, the court found that it "great[ly] and direct[ly] infrimge[d]"33 the woman's right of procreative choice.

In the twelve years between Belous and $C D R R$, three major cases implicating procreative choice came to the California Supreme Court. In each case the court failed to invoke the newly recognized riglit of procreative choice, leaving the scope of the right in doubt. In Ballard $v$. Anderson, ${ }^{34}$ the court construed Civil Code section $34.5^{35}$ and the Therapeutic Abortion $\mathrm{Act}^{36}$ to allow minors the opportunity to obtain therapeutic abortions without parental consent. While the Ballard decision perhaps reflected a tolerant view of abortion, the court did not find any incongruence between abortion restrictions on minors and the right of procreative choice. ${ }^{37}$ Similarly, in People v. Barksdale, ${ }^{38}$ the court struck down on vagueness grounds some of the abortion regulatory provisions of the Therapeutic Abortion Act. Although the lower court opinion had grounded its decision on the constitutional right of privacy, ${ }^{39}$ the supreme court refused to hold that the privacy-based procreative right announced in Belous liad been violated. ${ }^{40}$ Finally, in Bowland v. Municipal Court, ${ }^{41}$ the court uplield a state law that required those who assist witl childbirth to have state licenses. Tlie court refused to find that the statute impinged the right of procreative choice. $^{42}$

In sum, before $C D R R$ the court had recognized a right of procreative choice but its contours were somewhat in doubt. By contrast, the

32. Id.

33. Id. at 967,458 P.2d at 202, 80 Cal. Rptr. at 362 (the court's holding was limited to first trimester abortions). The court did not say whether more subtle state actions, such as those that discourage abortion or encourage childbirth, would also unconstitutionally infringe on the right of procreative choice.

34. 4 Cal. 3d 873, 484 P.2d 1345, 95 Cal. Rptr. 1 (1971).

35. Cal. Crv. Code $\$ 34.5$ (West 1954) (current version at West Supp. 1982).

36. Current version at CaL. Health \& SAfETY CODE \$\& 25950-25957 (West Supp. 1982).

37. Established principles of constitutional adjudication direct the court to attempt to resolve disputes by statutory construction and not reach possible constitutional issues. See, e.g., Ashwander v. TVA, 297 U.S. 288, 346-48 (1936) (Brandeis, J., concurring). Ballard and the other procreative right cases discussed in the text should therefore not be read as weakening the right of procreative choice.

38. 8 Cal. 3d 320, 503 P.2d 257, 105 Cal. Rptr. 1 (1972).

39. People v. Barksdale, 96 Cal. Rptr. 265 (1st Dist. 1971), officially depublished pursuant to CaL. Cr. R. 976(d) (West 1982).

40. Barksdale, 8 Cal. 3d at 326-27, 503 P.2d at 261-62, 105 Cal. Rptr. at 5-6.

41. 18 Cal. 3d 479, 556 P.2d 1081, 134 Cal. Rptr. 630 (1976).

42. Id. at 495,556 P.2d at 1089,134 Cal. Rptr. at 638. 
unconstitutional conditions doctrine had been extensively applied before $C D R R$ and its scope was better established.

\section{B. Doctrine of Unconstitutional Conditions}

The doctrine of unconstitutional conditions is based on the general constitutional principle that the government may not accomplish indirectly what it can not do directly. ${ }^{43}$ The doctrine states that the government may not condition the benefits it offers on the waiver or nonassertion of a constitutional right. ${ }^{44}$ By preventing the use of restrictions on constitutional rights as conditions on government benefit programs, the doctrine prevents the imdirect bargaining away of constitutional rights.

\section{Origin of the Doctrine}

The unconstitutional conditions doctrine origmated in the early part of this century in response to the case law recognition of a right/ privilege distimction. ${ }^{45}$ It was accepted that constitutional rights could generally not be directly conditioned; for example, the right of free speech could not be conditioned on the attainment of a college degree. On the other hand, it was argued, privileges offered by the government could be conditioned. ${ }^{46}$ Thus, the government could legitimately condition the benefits and opportunities that in its discretion it close to provide on the nonexercise of a constitutional right.

The proffered justification for the government's power to condition privileges was that simce the government had the greater power not to offer a benefit at all, it necessarily had the lesser power to offer the

43. See Van Alstyne, The Constitutional Rights of Public Employees: A Comment on the Inappropriate Uses of an Old Analogy, 16 U.C.L.A. L. REV. 751, 751 (1969). This principle is generally reflected in Suprene Court decisions on the scope of congressional power under the Constitution to regulate by taxing and by spending: Congress may not accomplish indirectly through regulatory taxing or conditioned spending what the Constitution will not let it do directly. L. TRIBE, AMERICAN CONSTITUTIONAL LAW 248 (1978).

44. The doctrine has been extensively discussed in the law review literature. For early treatments, see, e.g., Hale, Unconstitutional Conditions and Constitutional Rights, 35 ColuM. L. REv. 321 (1935); Merrill, Unconstitutional Conditions, 77 U. PA. L. Rev. 879 (1929). For more modern treatments, see Comment, Unconstitutional Conditions: An Analysis, 50 GEO. L.J. 234 (1961) [hereinafter cited as Analysis Comment]; Note, Unconstitutional Conditions, 73 HARv. L. REv. 1595 (1960) [hereinafter cited as Harvard Note]; Comment, Another Look at Unconstifutional Conditions, 117 U. PA. L. Rev. 144 (1968) [heremafter cited as Another Look Comment].

45. See e.g., Western Umion Tel. Co. v. Kansas ex rel. Coleman, 216 U.S. 1 (1910); Van Alstyne, The Demise of the Right-Privilege Distinction in Constitutional Law, 81 HARv. L. REv. 1439, 1440 (1968); Another Look Comment, supra note 44, at 145.

46. Packard v. Banton, 264 U.S. 140, 145 (1924). This view was implicit in the famous epigram of Justice Holmes, who, in rejecting the petition of a policeman who had been fired for violating a regulation restricting his political activities, stated: "The petitioner may have a constitutional right to talk pohtics, but he has no constitutional right to be a policeman." McAuliffe v. Mayor of New Bedford, 155 Mass. 216, 220, 29 N.E. 517, 517 (1892). 
benefit subject to whatever conditions it might impose. ${ }^{47}$ For example, since a state was not obligated to let a corporation conduct business within its boundaries, it was successfully mamtained that a state could grant this benefit on condition that the corporation forego removal of lawsuits to the federal courts. ${ }^{48}$ By this line of reasoning, many conditioned benefits were upineld. ${ }^{49}$

The use of the right/privilege distinction to validate conditioned government benefits has been largely rejected. Two reasons explain this rejection. First, while the distinction was justified in syllogistic terms, it is based on a logical fallacy. The uncontested premise is that the state is not obligated to offer a certain benefit. The asserted deduction is that the state may thus offer the benefit on any terms that it chooses. As a matter of strict logic, however, the deduction is unrelated to the premise. The power not to offer a benefit is different from, rather than greater than, the power to condition the offered benefit. ${ }^{50}$ The state's lack of obhgation to offer a benefit does not necessarily carry with it the power to condition the benefit. Thus, the right/privilege distinction can not be justified on the grounds of logic.

A second reason for the rejection of the right/privilege distinction is the threat that conditioned benefits could pose to the vitality of constitutional rights. Constitutional rights could be "bought up" if they had to be surrendered for benefits which im theory may be freely accepted or rejected but which in reahty may be necessary for one's livelihood.51 This threat to constitutional rights from an unchecked government power to condition benefits is particularly ominous in the era of the modern state. The enormous sweep of government welfare and regulatory programs and contractual arrangements could lead to the evisceration of constitutional rights if the government were not soinehow constrained in its exercise of a conditioning power. ${ }^{52}$ Thus, the courts rejected the right/privilege distinction and instead analyzed conditioned benefits under the unconstitutional conditions doctrime. ${ }^{53}$

47. E.g., Davis v. Massachusetts, 167 U.S. 43, 48 (1897).

48. See, e.g., Security Mut. Life Ins. Co. v. Prewitt, 202 U.S. 246, 252 (1906).

49. See, e.g., Doyle v. Continental Ins. Co., 94 U.S. 535, 542-43 (1876).

50. Analysis Comment, supra note 44, at 237. The classic refutation of "the greater includes the lesser" argument is Powell, The Right to Work for the State, 16 Colum. L. Rev. 99, 110-11 (1910) (responding to Western Union Tel. Co. v. Kansas ex rel. Coleman, 216 U.S. 1, 52 (1910) (Holmes, J., dissenting)) ("Mr. Justice Holmes is guilty here of the fallacy of four terms.") See also Harvard Note, supra note 44, at 1596-609 (offering a new refutation of the greater includes the lesser argument).

51. Frost v. Railroad Comm'r, 271 U.S. 583, 593 (1926).

52. See, e.g., Van Alstyne, supra note 45, at 1441; Harvard Note, supra note 44, at 1596.

53. The doctrine has been applied in many cases. See, e.g., cases cited infra notes 54-83. These cases often do not explicitly rely on the unconstitutional conditions doctrine as the basis of decision, however. Other principles that have an equivalent effect are often invoked; this is because government benefits conditioned on the nonassertion of a constitutional right are modernly 


\section{Scope of the Doctrine}

The unconstitutional conditions doctrine states a potentially farreaching rule. Almost any state activity can be characterized as a benefit. For example, government benefits include tax exemptions, ${ }^{54} \mathrm{em}-$ ployment, ${ }^{55}$ contracts, ${ }^{56}$ use of state property, ${ }^{57}$ and grants of probation. ${ }^{58}$ A condition based on the exercise of a constitutional right can also be broadly defined. Conditions can include limits on the freedom of the benefit recipient ${ }^{59}$ as well as the selection criteria that determine who can receive the benefit. ${ }^{60}$ For example, a benefit prograin for the poor could be said to burden freedoin of expression by requiring a potential recipient to fill out application forns. Such programs could conceivably violate the right to privacy by requiring the disclosure of personal and financial information. These examples suggest the potential reach of the doctrine. Applied so broadly, the unconstitutional conditions doctrine could invalidate a wide range of apparently reasonable conditions on current government benefits. ${ }^{61}$

To avoid an overly broad reach of the unconstitutional conditions doctrine, a number of principles limiting the doctrine's application have evolved. Some of these limitations are relevant to the abortion funding situation. First, the doctrine does not state an absolute rule. Courts balance the state interest in imposing the condition against the

suspect under several constitutional principles. For example, an unconstitutional condition may also fail under the fundamental rights branch of the equal protection clause. See, e.g., Shapiro v. Thompson, 394 U.S. 618 (1969). Additionally, an unconstitutional condition may be understood directly to infringe the right that is the subject of the condition. See, e.g., Sherbert v. Verner, 374 U.S. 398 (1963). Thus, when faced with a conditioned government benefit, a court may invoke any of several constitutional doctrines to hold that the condition infringes on a constitutional right. If a case strikes down a condition that requires a recipient to waive a constitutional right in order to enjoy a government benefit, this Note treats the case as decided under the unconstitutional conditions doctrine, even if the court did not specifically mvoke the doctrine.

54. See, e.g., Speiser v. Randall, 357 U.S. 513 (1958).

55. See, e.g., Keyishian v. Board of Regents, 385 U.S. 589 (1967).

56. Harvard Note, supra note 44, at 1602-05.

57. See, e.g., Lovell v. Griffin, 303 U.S. 444, 445 (1938).

58. See, e.g., In re Bushman, 1 Cal. 3d 767, 776, 463 P.2d 727, 732-33, 83 Cal. Rptr. 375, 38081 (1970); Note, Parole Status and the Privilege Concept, 1969 DukE L.J. 139.

59. See, e.g., United Public Workers v. Mitcliell, 330 U.S. 75 (1947) (restrictions on the political activities of federal employees).

60. See, eg., Shapiro v. Thompson, 394 U.S. 618 (1969) (residency rcquirements for welfare benefits).

61. O'Neil, Unconstitutional Conditions: Welfare Benefits with Strings Attached, 54 CALIF. L. REv. 443, 445 (1966). Giving such a broad effect to the doctrine would be a "manifest absurdity." It "would invalidate, among other things, all contracts to work for the state, for those require sacrifice of the constitutional right of idleness; or to sell it property, at least if the market value (and hence 'just compensation') should increase before delivery." Willcox, Invasions of the Fïst Amendment Through Conditioned Public Spending, 41 CoRNel. L.Q. 12, 25 (1955). 
seriousness of the indirect infringement. ${ }^{62} \mathrm{~A}$ number of government benefits that are conditioned on the nonassertion of a constitutional right have been upheld under such a balancing test. ${ }^{63}$

Second, the application of the doctrine varies depending on the strength and scope of the affected constitutional right. ${ }^{64}$ For example, a court is inore likely to find that a condition touching on a first amendment right is an unconstitutional condition than if the condition equivalently touches on some other constitutional right. ${ }^{65}$ The state is generally limited to a role of neutrality with respect to the expressions of first annendment rights, but is not so limited with respect to the exercise of other rights. ${ }^{66}$ Thus, the condition need not be as burdensome or intrusive in the first amendment area to be judicially declared an unconstitutional condition. ${ }^{67}$

A third limitation is that, outside the first amendment area, the only conditions on spending prograins that the cases have recognized as unconstitutional conditions are those that "penalize" the exercise of a constitutional right. Penalty conditions ${ }^{68}$ are distinguished from the "condition" of funding one expression of a constitutional right but failing to fund another expression of the right. ${ }^{69}$ It is this distinction between a penalty and a failure to fund, explained and discussed in detail in Part III, that the United States Supreme Court stressed in Maher $v$. Roe ${ }^{70}$ and Harris v. McRae ${ }^{71}$

62. Willcox, supra note 61, at 55; Another Look Comment, supra note 44, at 151, 156; see, e.g., United Pub. Workers v. Mitchell, 330 U.S. 75, 95-96 (1947).

63. See, e.g., Bordenkircher v. Hayes, 434 U.S. 357 (1978) (plea bargaining offer of lesser charge on condition that accused waive his right to trial upheld); United Pub. Workers v. Mitchell, 330 U.S. 75 (1947) (federal restrictions on political activities of civil servants upheld).

64. Another Look Comment, supra note 44, at 152-53.

65. See Note, Judicial Acquiescence in the Forfeiture of Constitutional Rights Through Expansion of the Conditioned Privilege Doctrine, 28 IND. L.J. 520, 527 (1953); Another Look Comment, supra note 44 , at $152-53$.

66. See infra text accompanying notes 163-71.

67. See supra note 49.

68. See, e.g., Shapiro v. Thompson, 394 U.S. 618, 634-38 (1969); Sherbert v. Verner, 374 U.S. 398, 403-06 (1963).

69. For example, nonpenalty conditions were distinguished and upheld in Carmichael v. Southern Coal \& Coke Co., 301 U.S. 495, 525-26 (1937), and Massaclusetts v. Mellon, 262 U.S. 447,482 (1923).

70. 432 U.S. 464 (1977). In Maher, the Court faced the issue of whether Connecticut, in the context of a state Medicaid program that paid for inost medical expenses including childbirth, could limit abortion funding to those that were "medically necessary." Maher analyzed the abortion funding restrictions in an equal protection framework. Because Connecticut's abortion funding restrictions placed no obstacles of the state's inaking in the path of an indigent woman who wanted an abortion, the Court concluded that it did not impinge the right of procreative choice. Id. at 474.

The Court found "a basic difference between direct state interference with a protected activity and state encouragenent of an alternative activity." $I d$. at 475 . The Court found this distinction imphicit in two earher cases. In Meyer v. Nebraska, 262 U.S. 390, 403 (1923), the Court struck 


\section{California Unconstitutional Condition Cases}

Danskin v. San Diego Unified School District ${ }^{72}$ heads the California line of unconstitutional condition cases. Danskin reviewed a state law ${ }^{73}$ that made the public use of school buildings conditional on the applicant's signing an oath that he did not advocate the overthrow of the United States government. Citing United States Supreme Court precedents, the California court adopted the principle that if the state cannot constitutionally impose a requirement directly, it may not do so imdirectly by nueans of a condition on a government benefit. ${ }^{74}$ Since the state could not directly infringe the rights of free speech and assembly unless a clear and present danger were found, the court held that it could not acconiplisli the same result indirectly. For that reason, the court invalidated the loyalty oath condition. ${ }^{75}$

The Danskin principle has simce been used in a wide variety of contexts. It has been applied, for exaniple, to governmental progranis of public eniploynent, ${ }^{76}$ welfare benefits, ${ }^{77}$ public housing, ${ }^{78}$ unem-

down a Nebraska law making it a crime to teach foreign languages to children who had not passed the eighth grade. In Pierce v. Society of Sisters, 268 U.S. 510, 534-35 (1925), the Court invalidated an Oregon criminal law requiring the parent to send his child to a public school. While both cases invalidated substantial state interfereuce with constitutionally protected liberty imterests, the Maher Court stated, neither case denied the state the choice of encouraging a preferred course of action.

The Court also distinguished several leading unconstitutional condition cases. In Shapiro v. Thompson, 394 U.S. 618, 634-38 (1969), and Memorial Hosp. v. Maricopa County, 415 U.S. 250, 253-62 (1974), durational residence requirements for the receipt of public assistance were declared unconstitutional because they "penalized" the exercise of the constitutional right to travel interstate. Justice Powell wrote that these "penalty analysis" cases would be analogous only if Connecticut demed general welfare benefits to women who obtained abortions. 432 U.S. at 474 n. 8 . Sherbert v. Verner, 374 U.S. 398 (1963) (invalidatimg a South Carolina statute that denied plaintiff employment benefits because, for religious reasons, she could not work on Saturdays) was distinguished because of the "constitutionally imposed 'government obligation of neutrality' origimating in the Establishment and Freedoin of Religion Clauses of the First Amendunent." 432 U.S. at 474 n.8.

71. 448 U.S. 297 (1980). In Harris the Supreme Court faced inore sweeping restrictions on abortion funding. At issue was the Hyde Amendment, Pub. L. No. 96-123, § 109, 93 Stat. 926 (1979), which eliminated federal funding of virtually all Medicaid abortions, includimg those that were "medically necessary." The Court found no reason to distinguish Maher even though it involved only nontherapeutic abortions, and rehed heavily on the Maher reasoning. The Court distinguished between the failure to fund protected conduct and a penalty on that conduct. The Court characterized the abortion funding restrictions as a simple refusal to fund, and rejected the argument that the restrictions unduly interfered with or penalized the woinan's procreative right. 448 U.S. at 316 n.19.

72. 28 Cal. 2d 536, 17I P.2d 885 (1946).

73. Act to Amend Section 19432 of the Education Code, ch. 1213, § 1, 1945 Cal. Stat. 230102 (repealed 1951).

74. $28 \mathrm{Cal} .2 \mathrm{~d}$ at $545-46,171$ P.2d at $890-91$.

75. Id at 554-55, 171 P.2d at 897.

76. See, e.g. , City of Carmel-by-the-Sea v. Young, 2 Cal. 3d 259, 466 P.2d 225, 85 Cal. Rptr. 1 (1970); Bagley v. Washmgton Township Hosp. Dist., 65 Cal. 2d 499, 421 P.2d 409, 55 Cal. Rptr. 401 (1966); Kinnear v. City \& County of San Francisco, 61 Cal. 2d 341, 392 P.2d 391, 38 Cal. 
ployment benefits, ${ }^{79}$ and the use of public property. ${ }^{80}$ It has been applied primarily where the constitutional right at issue was free speech ${ }^{81}$ or privacy. ${ }^{82}$ Thus, for example, it was applied in Bagley $v$. Washington Township Hospital District ${ }^{83}$ to strike down restrictions on political activities of public employees of a hospital district. The court found that Bagley was unreasonably required not to exercise a constitutional right as a condition for enjoying the benefit of government employment. While there arguably have been several cases where the California courts applied the unconstitutional conditions doctrine more expansively to reach a different result than the United States Supreine Court, ${ }^{84}$ California has generally followed the federal analysis. In $C D R R$, however, the court not only used the unconstitutional conditions doctrine to reach a different result than the United States Supreme Court had reached in Maher v. Roe ${ }^{85}$ and Harris v. McRae ${ }^{86}$ it also announced a new priniciple of California constitutional law.

\section{III}

\section{The Court's Unconstitutional Conditions Analysis}

Although the $C D R R$ court ${ }^{87}$ claimed to follow precedent, ${ }^{88}$ in fact it announced a new constitutional principle. This new principle - that

Rptr. 631 (1964); Fort v. Civil Serv. Comm'n, 61 Cal. 2d 331, 392 P.2d 385, 38 Cal. Rptr. 625 (1964).

77. See, e.g., Parrish v. Civil Serv. Comm'n, 66 Cal. 2d 260, 425 P.2d 223, 57 Cal. Rptr. 623 (1967).

78. See, e.g., Atkisson v. Kern County Hous. Auth., 59 Cal. App. 3d 89, 130 Cal. Rptr. 375 (5th Dist. 1976); Housing Auth. v. Cordova, 130 Cal. App. 2d Supp. 883, 279 P.2d 215 (1955).

79. See, e.g., King v. California Unemployment Ins. Appeals Bd., 25 Cal. App. 3d 199, 101 Cal. Rptr. 660 (5th Dist. 1972).

80. See, e.g., Binet-Montessori, Inc. v. San Francisco Unified School Dist., 98 Cal. App. 3d 991, 160 Cal. Rptr. 138 (1st Dist. 1979). (1967)

81. See, e.g., Vogel v. County of Los Angeles, 68 Cal. 2d 18, 434 P.2d 961, 64 Cal. Rptr. 409

82. See, e.g., City of Carmel-by-the-Sea v. Young, 2 Cal. 3d 259, 466 P.2d 225, 85 Cal. Rptr. 1 (1970); Parrish v. Civil Serv. Comm'n, 66 Cal. 2d 260, 425 P.2d 223, 57 Cal. Rptr. 623 (1967).

83. 65 Cal. 2d 499, 421 P.2d 409, 55 Cal. Rptr. 401 (1966). See also Wirta v. AlamedaContra Costa Transit Dist., 68 Cal. 2d 51, 434 P.2d 982, 64 Cal. Rptr. 430 (1967) (striking down bus advertising regulations prohibiting certain types of political messages); Parrish v. Civil Serv. Comm'n, 66 Cal. 2d 260, 425 P.2d 223, 57 Cal. Rptr. 623 (1967) (striking down warrantless comphance searches of welfare recipients' homes).

84. The CDRR court argued that three sets of cases illustrated that the California Supreme Court applied a different unconstitutional conditions analysis than the United States Supreme Court. $29 \mathrm{Cal}$. 3d at 266-67, 625 P.2d at 786-87, $172 \mathrm{Cal}$. Rptr. at 873-74. This argument may not be sound, however, since these cases differ with regard to significant facts. See infra note 92.

85. 432 U.S. 464 (1977).

86. 448 U.S. 297 (1980).

87. It is unclear to what extent Chief Justice Bird's concurring opinion supports the plurality's analysis. Although she agreed with the plurality that the abortion funding restrictions were uncoustitutional, she indicated that she reached that conclusion "by a somewhat different route." $29 \mathrm{Cal} .3 \mathrm{~d}$ at 286, $625 \mathrm{P} .2 \mathrm{~d}$ at 799, $172 \mathrm{Cal}$. Rptr. at 886 (Bird, C.J., concurring). 
the court will strictly scrutinize ${ }^{89}$ the selective funding of constitutional rights in general benefit programs ${ }^{90}$ —extends the reach of the unconsti-

Bird read the California cases as standing for a broader rule against selective funding than the one announced in the lead opinion. She cited Danskin as "stand[ing' for the proposition that the state inay not grant benefits in a inanner which discriminates against the exercise of fundainental rights." Id. at 296, 625 P.2d at 806, 172 Cal. Rptr. at 893. This broad interpretation subjects virtually any selective funding scheine to strict scrutiny, regardless of whether it is part of a general benefit program.

Bird analyzed the selective funding of childbirth as an indirect infringement of a fundamental right, but she rejected the notion that there was any constitutional difference between a direct and an indirect infringement of a right. $I d$. at 288-89 \& n.2, 625 P.2d at 801-02 \& n.2, 172 Cal. Rptr. at 888-89 \& n.2. Since there was no constitutional distinction between direct and indirect infringements, it followed that all such infringenents were scrutinized under the same standard of review. Thus, Bird rejected the special Bagley test and would have subjected the abortion funding restrictions to the traditional strict scrutiny test. $I d$.

88. Id. at 263-64, 625 P.2d at 785-86, 172 Cal. Rptr. at 872-73.

89. $C D R R$ leaves unresolved precisely what fornulation of strict scrutiny to apply. The plurality used the Bagley test, $i d$, at $258,625 \mathrm{P} .2 \mathrm{~d}$ at $781,172 \mathrm{Cal}$. Rtpr. at 868 , but Chief Justice Bird strongly rejected it as outdated, $i d$. at 289 n.2, 625 P.2d at $801 \mathrm{n} .2,172$ Cal. Rptr. at 888 n.2.

In any case, the plurality's analysis in applying Bagley, see supra notes 18-20 and accoinpanying text, is flawed. The Bagley test's first prong is that the state must estabhsh that the imposed conditions relate to the purposes of the legislation which confers the benefit or privilege. The legislatively declared purpose of Medi-Cal is to "afford health care and related reinedial or prcventive services to recipients of public assistance and to inedically indigent, aged, and other persons." CAL. Welf. \& INST. CODE $\$ 14000$ (West 1980). CDRR concluded that the primary purpose of Medi-Cal was to pay for the medical expenses of poor people and that the abortion funding restrictions directly impeded that purpose, thus failing the first prong of the Bagley test. 29 Cal. 3d at 271-73, 625 P.2d at 790-91, 172 Cal. Rptr. at 877-78.

$C D R R$ 's construction of legislative purpose is unprincipled. Legislative purpose is tautological with the plain terms of a statute: the legislature means what it plainly says. See Note, Legislative Purpose, Rationality, and Equal Protection, 82 YALE L.J. 123, 128 (1972). In CDRR, the siniple words of the statute and the abortion funding restrictions show that the legislature's purpose was to pay for most of the inedical expenses of poor people, except for abortion expenses. Under the construction of legislative purpose inaugurated in $C D R R$, it would almost always be possible to read a statute's purpose so broadly that any limiting conditions contradict the judicially understood purpose of the statute.

90. $29 \mathrm{Cal} .3 \mathrm{~d}$ at 262,625 P.2d at 789,172 Cal. Rptr. at 871 (Tobriner, J.).

The court restated the principle it apparently relied on in a number of different ways, making it difficult to state the $C D R R$ principle with certainty. Sometimes it stated a fornulation against selective funding that seemed to limit the principle to general benefit prograins for the poor. See, e.g., id. at 256-57, 262, 284-85, 625 P.2d at 781, 784, 798-99, 172 Cal. Rptr. at 868, 871, 885-86. The court also cited a law review article recommending that a spocial scheme of unconstitutional conditions analysis be developed for government programs that affect the poor. $I d$. at 281-82, 625 P.2d at 797, 172 Cal. Rptr. at 884 (citing O'Neil, supra note 61).

At other times the court stated a broader fornulation against selective funding that ounitted the qualification of a program for the poor. See, e.g., 29 Cal. $3 \mathrm{~d}$ at 257, $625 \mathrm{P.2d}$ at 781, $172 \mathrm{Cal}$. Rptr. at 868 ("'a discriminatory or restricted government benefit program deinands special scrutiny whether or not it erects some new or additional obstacle that inipodes the exercise of constitutional rights"); id. at 264, 625 P.2d at 786, 172 Cal. Rptr. at 873 ("California courts have repeatedly rejected the argument that becanse the state is not obligated to provide a general benefit, it inay confer such a benefit on a selective basis which excludes certain recipients solely because they seek to exercise a constitutional right.") Moreover, one footnote strongly iniphed that the general benefit program idea is the essential part of the rule. See id. at 270 n.19, 625 P.2d at 789 n.19, 172 Cal. Rptr. at 876 n.19. 
tutional conditions doctrine. Analysis demonstrates that the court's attempts to justify this selective funding principle are flawed. ${ }^{91}$ Moreover, significant pohicy considerations weigh against this selective funding principle.

\section{A. A New Principle Against the Selective Funding of Constitutional Rights}

\section{Selective Funding of a Constitutional Right Is Not a "Penalty"}

The court failed to acknowledge that the selective funding involved in $C D R R$ is different from the conditions at issue in the Danskin line of cases. ${ }^{92}$ Those cases all involved conditions that "penalized" the exercise of a constitutional right. To state the penalty idea abstractly, a condition penalizes a person for the exercise of a constitutional right when it causes the person to forfeit some benefit she otherwise would have received but for the particular exercise of the right. In contrast, a simple failure to fund (such as selectively funding one exercise of a right but not another) ineans that the state inerely does not reimburse a

The court's references to programs for the poor may merely reflect the fact that the Medi-Cal program before the court is designed to aid the poor. The fact that the majority of the court's references omit the poverty qualification suggests that the court does not intend for its rule to be limited to programs for the poor.

91. In defending its selective funding principle, in addition to the arguments discussed infra in the text, the court sought to distinguish its approach to unconstitutional conditions cases from that employed by the United States Supreme Court. In support of the asserted distinction, the California Supreme Court cited three cases in which it had struck down a condition while the United States Supreme Court had upheld a "similar" condition. Id. at 266-67, 625 P.2d at 786-87, $172 \mathrm{Cal}$. Rptr. at 873-74. Inspection of these case reveals that they differ with regard to key facts, however, and thus it is not clear that the California Supreme Court has applied the unconstitutional conditions doctrine more broadly than has the United States Supreme Court. Compare, Umited States Civil Serv. Comm'n v. National Ass'n of Letter Carriers, 413 U.S. 548 (1973) (upholding restrictions on the partisan political activities of federal employees) with Fort v. Civil Service Comm'n, 61 Cal. 2d 331, 392 P.2d 385, 38 Cal. Rptr. 625 (1964) (striking down for overbreadth a county ordinance prohibiting public employees from participating in partisan or nonpartisan political activities); compare Lehman v. City of Shaker Heights, 418 U.S. 298 (1974) (upholding public transit policy of accepting commercial but not political advertising, on grounds that such a policy did not make the public transit a public forum) with Wirta v. Alameda-Contra Costa Transit Dist., 68 Cal. 2d 51, 434 P.2d 982, 64 Cal. Rptr. 430 (1967) (striking down a policy of accepting commercial and election advertising but not other political advertising, on grounds that such a policy created a public forum); compare Wyman v. James, 400 U.S. 309 (1971) (periodic prescheduled daytime home visitations by welfare caseworker are not a fourth amendinent search; New York statutes and regulation requiring sucl visitations for continuation of welfare benefits upheld) with Parrish v. Civil Serv. Comm'n, 66 Cal. 2d 260, 425 P.2d 223, 57 Cal. Rptr. 623 (1967) (unannounced dawn searclies of welfare recipients hoines are an unreasonable searcli and seizure under the fourth amendment). The Wyman court specifically withheld judgment on a situation involving the Parrish facts. Wyman, 400 U.S. at 326.

92. A rule against selective funding has been recognized in first amendınent cases, but it has not been apphed outside the special context of the first amendinent. See infra text accompanying notes 163-71. 
person for the cost of some specific behavior..$^{93}$

$C D R R$ involves a simple failure to fund. The only consequence of a woman's choosing to have an abortion is that she is not reimbursed for the costs of that choice. She loses nothing that she would otherwise receive if she did not choose an abortion. In other words, the benefits she can receive under Medi-Cal are the saine whether or not she chooses an abortion. In contrast, a true penalty in the abortion funding area would occur if the state cut off all Medi-Cal benefits to a woman choosing an abortion. In this penalty example, the woinan who has had an abortion has lost solnething other than a subsidy for her abortion; this soinething else is the penalty.

In Maher v. Roe ${ }^{94}$ and Harris v. McRae, ${ }^{95}$ the United States Supreine Court based its decisions upholding abortion funding restrictions on the fact that the restrictions represented only a simple failure to fund. The Court held that the abortion funding restrictions were not unconstitutional conditions because the funding restrictions did not penalize the exercise of a constitutional right. The Court distinguished a situation where a woman would lose other benefits if she had an abortion froin a situation where the state inerely refused to fund abortion. Only in the former situation was the woman penalized, the Court held, and thus an unconstitutional condition was present only where she would lose benefits other than reimburseinent for abortion. ${ }^{96}$

The $C D R R$ court declined to adopt the penalty/failure to fund distinction applied in Maher and McRae.$^{97}$ By doing so, the court signaled its willingness to apply the unconstitutional conditions doctrine to simple failure to fund situations. It failed to acknowledge, however, that none of the cases in the Danskin line, upon which the court rehed,

93. Tribe, in Choper, Kamisar \& Tribe, Harris v. McRae: A Panel Discussion, in J. CHOPER, Y. Kamisar, \& L. Tribe, The Supreme Court: Trends and Developments, 1979-1980, at 289-91 (1981) [hereinafter cited as TRENDS AND DevelopmenTs, 1979-1980]; Harris v. McRae, 448 U.S. 297,317 n.19 (1980); Maher v. Roe, 432 U.S. 464, 474 n.8 (1977). See Canby, Government Funding, Abortions, and the Public Forum, 1979 ARIz. ST. L.J. 11, 16; Hardy, Privacy and Public Funding: Maher v. Roe as the Interaction of Roe v. Wade and Dandridge v. Williams, 18 ARIZ. L. REv. 903, 912 n.51 (1976). But cf. Choper, Discrimination Against the Poor and Fundamental Rights, in TRENDS AND DEvELOPMENTS, 1979-1980 supra, at 80 ("this is a clear illustration of placing an unconstitutional condition on the use of government funds"); The Supreme Court, 1979 Term, 94 HARv. L. REv. 75, 100 \& n.28. (1980) (the distinction between a penalty and a failure to fund is irrelevant; the issue is whether the state interest is coustitutionally forbidden).

94. 432 U.S. 464 (1977).

95. 448 U.S. 297 (1980).

96. Some judges and commentators, however, in addressing the abortion funding issue, have rejected the notion that there is this penalty limitation on the reach of the unconstitutional conditions doctrine. See, e.g. , Harris v. McRae, 448 U.S. 297, 336 (1980) (Breunan, J., dissenting); id. at 345-46 (Marshall, J., dissenting); Goldstein, A Critique of the Abortion-Funding Decisions: On Private Rights in the Public Sector, 8 Hastings ConST. L.Q. 313, 330-31 (1981).

97. See 29 Cal. 3d at 257, 625 P.2d at 781, 172 Cal. Rptr. at 868; id. at 294-95, 625 P.2d at 805, 172 Cal. Rptr. at 892 (Bird, C.J., concurring). 
had arisen in a failure to fund context and that it had never before recognized a general rule against the selective funding of constitutional rights.

All of the Danskin line of conditioned benefit cases involved penalties. For example, in Bagley v. Washington Township Hospital District ${ }^{98}$ a nurse's aide employed by a public hospital authority was fired for refusing to discontmue off-duty political activities. The condition placed on the benefit of public employment - prohibition of political activity-did not merely call for the nonfunding of this off-duty activity. The condition caused Bagley to lose a benefit she would otherwise have received but for her political activity-the benefit of public employsnent. Thus, the condition restricting political activity was properly struck down as penalizing the exercise of a constitutional right. A failure to fund example can be constructed on facts similar to Bagley: if the hospital provided paid time off for voting, but would not subsidize time spent on local electoral activity, that would be a simple failure to fund. Since the failure to fund is not a penalty, it would not be struck down under the main line of unconstitutional condition cases.

Danskin v. San Diego Unified School District ${ }^{99}$ involved a penalty. ${ }^{100}$ In Danskin, persons who sought free use of a school auditorium had to sign a loyalty oath, affirming that they did not favor the violent overthrow of the United States government. If a person did not sign the oath, he would be denied the use of the auditorium even if lie wished to use it for a purpose that had nothing to do with the overthrow of the government. This was not a simple failure to fund. A person was not denied reimbursement for the behavior of favoring the violent overthrow of the United States government; rather the statute penalized those who held that belief by denying them the benefit of free use of the school auditorium. ${ }^{101}$

It is possible, of course, to characterize the funding of one expression of a constitutional right but not of another as a penalty, because the person choosing the unfunded expression receives no reimburse-

98. 65 Cal. 2d 499, 421 P.2d 409, 55 Cal. Rptr. 401 (1966).

99. 28 Cal. 2d 536, 171 P.2d 885 (1946).

100. Danskin is a public forum case. As such, it falls within a special line of first amendment cases in which selective funding is struck down because of the neutrality imposed on the government by the first amendment. See infra text accompanying notes 163-71. Because the CDRR court rehes so heavily on the Danskin analogy, it is used here to illustrate the difference between a penalty and a simple failure to fund.

101. A failure to fund example can also be constructed on facts close to Danskin. If the state denied the free use of its auditorium for speeches advocating the overthrow of the government, then that would be a simple failure to fund. Since Danskin is a first amendment public fornm case, however, a court wonld strike down even a failure to fund if the effect were not content nentral. See infra text accompanying notes 163-71. 
ment. ${ }^{102}$ The unconstitutional conditions cases do not support using "penalty" in such a far-reaching sense, however. It is also possible to characterize both the $C D R R$ and Danskin cases as involving a failure to fund-in CDRR, the failure to fund abortion, and, in Danskin, the failure to fund the speech of those who refuse to sign loyalty oaths. But, once again, this misuses a term of art and obscures the fundainental distinction between $C D R R$ and the Danskin cases: the former involved a simple failure to reimburse disfavored behavior while the latter involved withholding benefits that otherwise would have been received but for the disfavored behavior.

\section{The Intraracial Marriage Hypothetical}

Responding to arguments that precedent did not support application of the unconstitutional conditions doctrine to the $C D R R$ facts, the court analogized to a hypothetical situation. It reasoned that a court would surely strike down a government program that subsidized intra racial marriages but not inter racial ones. ${ }^{103}$ The court concluded that this hypothetical shows that the rule against selective funding is not a new one. The liypothetical is inapposite, however; with it the court erroneously invoked a separate line of analysis under which some selective funding schemes have been found constitutionally infirm. The hypothetical is distinguishable froin $C D R R$ because the selective funding of intraracial marriages classifies on the basis of the suspect class of race. Because the fourteenth amendinent was specifically directed against racial discrimination, the equal protection clause is understood to require that racial classifications must always be strictly scrutinized. ${ }^{104}$

On the other hand, a classification based on the exercise of a fundamental right, such as procreative choice, is strictly scrutinized under the equal protection clause only where the exercise of the right is "impinged"-that is, inore than minimally interfered with or burdened. ${ }^{105}$ For example, a program that classified on the basis of pregnancy and that provided special inedical services for pregnant inothers would not likely be considered an impingeinent of the right of procreative choice,

102. See Harris v. McRae, 448 U.S. 297, 336 (1980) (Brennan, J., dissenting); id. at 345-46 (Marshall, J., dissenting).

103. $29 \mathrm{Cal} .3 \mathrm{~d}$ at $268-69,625 \mathrm{P} .2 \mathrm{~d}$ at $788,172 \mathrm{Cal}$. Rptr. at 875 .

104. See, e.g., Loving v. Virginia, 388 U.S. 1 (1967).

105. The Supreme Court finds an impingement of a right only where there is a sufficiently serious invasion of a right, so that it is "deprived," "infringed," or "interfcred with," only such an impingement is subject to strict scrutiny. State actions that only "touch upon" or "mcidentally impact" the right do not constitute an impingement and are reviewed under the solicitous rational relationship test. Appleton, Beyond the Limits of Reproductive Choice: The Contributions of the Abortion-Funding Cases to Fundamental-Rights Analysis and to the Welfare-Rights Thesis, 81 COLUM. L. REv. 721, 746-47 (1981). 
necessitating strict scrutiny and a coinpelling state interest, because the interference with the right is so minor. Not every classification based on the exercise of a fundamental right is an impingeinent. Indeed, the $C D R R$ court imphicitly concedes that not all selective funding is an impingement, since it would apparently allow the state without special justification to fund childbirth but not abortion when the selective funding is not part of a "general benefit" program. ${ }^{106}$ This can be contrasted with a special subsidy program for whites only, which would surely not receive such deference. Thus, since the court applies different analyses and standards of review to racial and fundamental rights classifications, the $C D R R$ court's intraracial marriage hypothetical cannot support its rule agamst the selective funding of constitutional rights.

\section{The Relevance of Pierce v. Society of Sisters}

The court also responded to an argument that its decision was inconsistent with Pierce $v$. Society of Sisters. ${ }^{107}$ In Pierce, the United States Supreme Court rccognized a constitutional right to attend a private school but did not apply a selective funding rule to require the funding of private schools. The $C D R R$ plurality opimion, perhaps anticipating a challenge to California's practice of selectively funding public but not private schools, attempted to distinguish the school funding situation by stating that the government would not have to subsidize one who rejected a public benefit for a "coinparable" private benefit. $^{108}$

The comparable benefit distinction, however, does not withstand analysis. The recognition of a right to choose whether to attend a public or private school reflects the fact that the two types of schools are not coinparable, at lcast to the person making the choice. The "comparable" benefit idea seems to define away the constitutional right, at least for purposes of the selective funding rule, by suggesting there is no difference between public and private schools, and thus suggesting no right to attend a private one. Thus, the court failed to offer any persuasive reason why its selective funding rule should not be applied to schools. If there were a general rule agamst selective funding, then the court would lave to apply it to the selective funding of public schools.

In sum, analysis of the $C D R R$ opinion reveals that the authority offered by the court as precedent for its decision does not support appli-

106. See 29 Cal. 3d at 270 n.19, 625 P.2d at 789 n.19, 172 Cal. Rptr. at 876 n.19. See infra notes 118-31 and accompanying text.

107. 268 U.S. 510 (1925). See also Norwood v. Harrison, 413 U.S. 455, 462 (1973) (private schools have no equal protection right to state educational funds).

108. 29 Cal. 3d at 269, 625 P.2d at 788-89, 172 Cal. Rptr. at 875-76. 
cation of the unconstitutional conditions doctrine in the selective funding context. Since the court's principle thus lacks precedential support, it can only be justified if adequately supported by policy considerations. The following section argues that rather than supporting the court's new principle, policy considerations argue against the extension of the unconstitutional conditions doctrine to selective funding cases.

\section{B. Problems With the Selective Funding Principle}

On balance the court was wrong to announce the new principle against selective funding. The rule against selective funding unwisely restricts the power of majoritarian institutions to encourage certain preferred activities and threatens to disrupt many existing benefit programs. Moreover, by only applying to "general" benefit programs, the selective funding principle's reach is limited in a manner that is inconsistent with the policy concern on which the principle is based. Indeed, the general benefit program qualification provides a loophole for selective funding programs, and may lead to a greater erosion of constitutional rights and greater hardship on government benefit recipients than if the selective funding principle had not been announced at all.

\section{Excessive Restriction on Governmental Activity}

The selective funding rule goes far toward requiring the government to be neutral with respect to the exercise of constitutional rights. This is contrary to established doctrine, since the constitution has not been read to require neutrality generally. ${ }^{109}$ Established doctrine in this area is sound. While the California Constitution prevents the state from prohibiting or interfering with certain activities, it should not be read to require the state to be indifferent towards the exercise of constitutional rights. Such a reading would excessively restrict the majority and threaten many existimg programs.

The selective funding rule would excessively restrict the state in two ways. First, it would prevent the state from aiding the exercise of a constitutional right unless the state was able to fund all exercises of that right. For example, the state might wish to provide a vacation for underprivileged youths by funding annual excursions to parks in neighboring states. By selectively funding trips only to nearby states, however, the program would seem to infringe on the exercise of the right to travel smce it selectively funds only some interstate travel. ${ }^{110}$ The $C D R R$ selective funding rule could prohibit the state from subsi-

109. Tribe, supra note 93 , at 290 . The neutrality principle is applied in the first amendment context. See infra text accompanying notes 163-71.

110. The fundamental right to travel was first recognized in Shapiro v. Thompson, 394 U.S. 618 (1969). 
dizing vacation trips for youths unless the state funded trips to all states. In this way, $C D R R$ may discourage government benefits prograns, since the state fisc cannot afford to fund all exercises of all the constitutional rights that may be affected by such programs.

The second way that the selective funding rule excessively restricts the state is that it prevents the political majority from encouraging certam behavior thought to be socially desirable. For example, the majority nay feel that marriage is an imstitution that is important to the health of society. The legislature may wish to provide a financial reward to those who marry, ${ }^{111}$ or free counseling for those contemplatimg divorce, in order to support the mstitution of inarriage. The right to marry and divorce is constitutionally protected, ${ }^{112}$ however, so the selective funding rule would prohibit such favoritism. It would require the majority to be indifferent to activities once they are deemed to be constitutional rights. It is one thing to hold that the state may not prevent or penalize the exercise of a constitutional right. It goes much further to hold that the majority may not favor some expression of the right. Such a holding goes too far in preventing the majority from encouraging the types of behavior it deems most worthy. As such, $C D R R^{\prime}$ 's prohibition of selective funding may result in undue judicial interference with what have been traditionally understood to be proper legislative concerns. ${ }^{113}$

By so restricting the scope of government activity, the court's selective funding principle also throws into doubt the constitutionality of inany existing programs. One example would be the separate tax rate schedules for married and single persons. ${ }^{114}$ Providing different economic benefits depending upon whether a person has exercised his constitutional right to marry seems to violate the selective funding rule. Another example would be the policy of providing dormitory residences for students at state universities, but limiting rooin assignments to students of the same sex. The result of this policy is that single persons of the opposite sex wishing to live together inust forego state subsidized housing and move off campus. This restriction on coed dormitory living seems to conflict with City of Santa Barbara v. Adamson, ${ }^{115}$ which held that the constitutional right of privacy protects the

111. Special tax rates for married couples, see, e.g., CAL. Rev. \& TAX CODE $\$ \S 17041,17045$ (West Supp. 1981), are one possible example of such rewards.

112. Loving v. Virginia, 388 U.S. 1 (1967) (recognizing fundamental right to marry). The fundamental right to terminate a marriage underlies Boddie v. Connecticut, 401 U.S. 371 (1971).

113. Cf. Cramtou, Nonstatutory Review of Federal Administrative Action: The Need for Statutory Reform of Sovereign Immunity, Subject Matter Jurisdiction, and Parties Defendant, $68 \mathrm{MicH}$. L. REv. 387, 397 (1970) (government actions should be protected from undue judicial influence).

114. See supra note 111 .

115. 27 Cal. 3d 123, 610 P.2d 436, 164 Cal. Rptr. 539 (1980). 
personal choices of unrelated persons to hive together. The pohcy of providing only single sex room assignments selectively funds the Adamson right. Thus, it appears to be unconstitutional under the $C D R R$ selective funding rule.

These examples suggest the potentially far-reaching and undesirable effect of the selective funding principle on the ability of government to fashion limited programs to address felt needs. The principle would greatly limit the ability of majoritarian institutions to encourage behavior that is thought to be socially desirable as well as within the proper scope of majoritarian control. ${ }^{116}$ Such a sweepimg restriction of majoritarian rule would significantly increase the weight of the constitution's "dead hand," and the power of a judiciary that uses that document to protect an expanding hist of nontextual fundamental rights.

\section{The Principle is Underinclusive}

The pohcy concern underlymg the unconstitutional conditions doctrine is that the state will use its largesse to "buy up" or bargam away citizens' constitutional rights. ${ }^{117}$ If government may not directly prevent the exercise of a constitutional right, it should not be able to do so indirectly by means of a condition on a benefit. But this policy concern is too broad to justify the new principle announced by the court. If that pohcy concern were given effect in the selective funding area, it would require that strict scrutiny be given to every government prograin that did not fund equally all expressions of an affected constitutional right. Thus, even if the court were right to treat selective funding as an unconstitutional condition, it was wrong to limit this protection to general benefit programs.

\section{a. The Definition of a General Benefit Program}

In inost of its formulations of the $C D R R$ rule against selective funding, the court limited the rule's reach to general benefit programs. ${ }^{118}$ Yet nowhere did the court define what a general benefit program is. Nor does a definition appear in the Danskin-Bagley line of cases, although the court cited those cases as the source for the classification. Thus, the threshold problem is to determine what the court meant by a general benefit program.

Since the court cited the Danskin-Bagley line of cases for the general benefit program concept, ${ }^{119}$ the boundaries of the concept ought to

116. See Monaghan, The Constitution Goes to Harvard, 13 HARv. C.R.-C.L. L. REv. 116, 131 (1978).

117. E.g., Frost \& Frost Trucking Co. v. Railroad Comm'r, 271 U.S. 583, 592-93 (1926).

118. See, e.g., 29 Cal. 3d at 256, 270, 625 P.2d at 781, 789, 172 Cal. Rptr. at 868, 876.

119. CDRR, $29 \mathrm{Cal} .3 \mathrm{~d}$ at $270,625 \mathrm{P} .2 \mathrm{~d}$ at $789,172 \mathrm{Cal}$. Rptr. at 876. 
be somewhere within the common set of characteristics of the benefit programs involved in those cases. Yet the programs at issue in those cases vary considerably in scope and character. Bagley involved public employment with a local hospital district organization. ${ }^{120}$ Parrish $v$. Civil Service Commission ${ }^{121}$ concerned a county general welfare program. Danskin itself involved a program that allowed sclool buildimgs to be used for public meetings. ${ }^{122}$ There is no unifying theme running through these cases that would define a general benefit program. Likewise, the size and scope of the programs $C D R R$ intended to reacl is unclear. The benefit programs in Bagley and Danskin are not very general at all. They both involve smgle benefits that are enjoyed by only a small part of the public. Extrapolating from the benefit programs in Bagley and Danskin, it would appear that most state programs would be defined as general benefit programs. The $C D R R$ court suggested, however, that a program that funded childbirth alone would not be such a general benefit program. ${ }^{123}$ It is hard to reconcile the treatment of the single benefit programs in Danskin and Bagley as general benefit programs with the suggestion that funding childbirth alone would not be a general benefit program.

Nor is it possible to deduce the nature of the general benefit concept by examining the possible explanations for why the court so limited its holding. There are several possible explanations. The qualification may have its origin in an analogy to the public forum concept. One law review article suggested that just as the existence of a public forum requires that state regulations be evenhanded with regard to the content of the freedom of expression, so the existence of a general benefit program for medical services obligates the state to fund procreative alternatives evenhandedly. ${ }^{124}$

The public forum analogy raises two problems, lowever. First, the analogy between a public forum and a general benefit program is quite strained. According to the classic formulation, public forums are those places, such as streets and parks, that have traditionally been used for purposes of assembly and for discussing public questions. ${ }^{125}$ Because the purposes and characteristics of a public forum are so different from those of a benefit program, it is difficult to analogize from the former to the latter. Second, the existence of a public forum triggers certaim rights of access to the forum. ${ }^{126}$ In the procreative area,

120. 65 Cal. $2 \mathrm{~d}$ at 502-03, 421 P.2d at 412,55 Cal. Rptr. at 404 .

121. $66 \mathrm{Cal} .2 \mathrm{~d} \mathrm{260,} 425$ P.2d 223, $57 \mathrm{Cal}$. Rptr 623 (1967).

122. $28 \mathrm{Cal} .2 \mathrm{~d}$ at $538-40,171 \mathrm{P} .2 \mathrm{~d}$ at $887-88$.

123. See 29 Cal. $3 \mathrm{~d}$ at $270 \mathrm{n} .19,625 \mathrm{P} 2 \mathrm{~d}$ at $789 \mathrm{n} .19,172$ Cal. Rptr. at $876 \mathrm{n} .19$.

124. Canby, supra note 93 , at $16-17$.

125. Hague v. ClO, 307 U.S. 496, 515 (1939) (Roberts, J.) (plurality opinion).

126. Stone, Fora Americana: Speech in Public Places, 1974 SuP. CT. Rev. 233, 239-45. 
this implies an affirmative obligation to provide funding for abortion and other procreative alternatives, even if the program did not selectively fund childbirth. ${ }^{127}$ But the $C D R R$ court specifically denied that it was imposing an affirmative state obligation to fund procreative alternatives absent the funding of one sucli alternative. ${ }^{128}$ For these two reasons, the public forum concept is not analogous to the court's general benefit concept.

The general benefit program qualification also might have been based on the presumption that selective funding of constitutional rights in a general prograin context is always meant to discriminate against the exercise of unfunded rights. ${ }^{129}$ The court inay have felt that selective funding in this context is sufficiently suspect to require strict scrutiny of the state's classification. This presumption of discriminatory state purpose may be justified witl regard to the unique situation in which childbirth is funded but abortion is not, since the state cannot argue that it is not funding abortion to save money. ${ }^{130}$ The presumption stands on weaker ground for other constitutional rights, however, since selective funding may be based on the legitimate state purpose of conserving the public fisc. For exainple, the state inay wish to provide disadvantaged youths with vacations, but only to nearby states, to save limited funds. It does not seem correct to presume that the state's purpose is to discriminate against travel to more distant states. Thus, if it is based on a presumption of discriminatory state purpose, the general benefit prograin is poorly designed since such a presumption is frequently not warranted.

In sum, neither by examining the precedents on which the court relied nor by examining the possible reasons for limiting the selective funding programs to general benefit programs can it be determined precisely what the $C D R R$ court ineant by its general benefit qualification. It is clear, however, that the court did not intend its primciple to apply to every situation in which the state selectively funds the exercise of a constitutional right. This fact makes the court's general benefit qualification vulnerable to two criticisms.

127. See Canby, supra note 93, at 13-15.

128. 29 Cal. $3 d$ at 256,625 P.2d at 780,172 Cal. Rptr. at 867 .

129. See id. at 256, 276, 625 P.2d. at 780, 793, 172 Cal. Rptr. at 867, 880.

130. The state will pay many times more in maternity care and childbirth expenses than it would save by refusing to fund abortion. Id. at $277 \& \mathrm{n} .23,625$ P.2d at $794 \& \mathrm{n} .23,172 \mathrm{Cal}$. Rptr. at $881 \&$ n.23. It is not altogether certain, however, that most indigent women will opt for childbirth rather than abortion if the state funds the former but not the latter. Some doctors and private clinics, perhaps supported by donations, may be willing to provide abortions to poor women for little or no charge. Moreover, many women may conclude that in the long run it will be less expensive for them to pay for their own abortion than to have a child. 


\section{b. Criticism of the General Benefit Program Qualification}

The first criticism is that the court's general benefit limitation is not responsive to the harm that the court has identified: the burdening of imdigents' right of procreative choice. The court found that funding childbirth but not abortion would "severely impair or totally deny" poor women the exercise of the right of procreative choice, and that it is a "significantly greater impairment" than almost all the past California unconstitutional condition cases. ${ }^{131}$ If that is true, then poor women's rights are no less impaired because the selective funding occurs in the context of a nongeneral benefit program rather than im the context of a general Medi-Cal program. Simply, the court's express limitation overlooks the court's identified harm.

The second criticism is that the general benefit program qualification may eventually prove counterproductive to public benefits for the poor. Where the state wishes selectively to fund only certaim expressions of a constitutional right, the $C D R R$ qualification gives the legislature an imcentive to structure very narrow benefit programs im order to avoid the general benefit rule. This could lead to the perverse result of the state being less generous in meeting the needs of the poor than it otherwise would be in order to avoid the "general" benefit rule. For example, if the legislature were determined enough not to fund abortion, apparently it could avoid abortion funding by abolishing Medi$\mathrm{Cal}$ and settimg up a program that funded childbirth alone. Tlius, the general benefit program qualification could result in fewer benefits for the poor.

\section{IV}

The Right of Procreative Choice: A Proposed

\section{Neutrality Principle}

The analysis in Part III focused on the shortcomings of the court's rule extending the unconstitutional conditions doctrine to the selective funding of constitutional rights. This Part IV argues that a better approach to the issue posed by $C D R R$ would be to require the state to act neutrally with regard to expressions of the right of procreative clioice. This neutrality requirement would be based on the special importance of the right of procreative choice in the California constitutional scheme and would impose obligations analogous to the governmental requirement of neutrality that has been recognized in inany contexts with regard to first amendment rights. The proposed rule would make the selective funding of childbirth but not of abortion (or vice-versa) subject to strict scrutiny; but it would do so because of the special im-

131. 29 Cal. 3d at 276, 625 P.2d at 793, 172 Cal. Rptr. at 880 . 
portance of the procreative choice constitutional right, not because of a general principle applicable to all constitutional rights such as that announced by the $C D R R$ court.

\section{A. The Importance of the Right of Procreative Choice Under the California Constitution}

Before $C D R R$ it was unclear whether the state's interest in protecting a nonviable fetus could outweigh the woman's right of procreative choice. ${ }^{132} C D R R$ resolved this question, holding that the state's interest in potential human life could not prevail over the wornan's right of procreative choice. This conclusion was premised on three related holdings, which together significantly strengthen the protection accorded to the procreative right in California.

The court first held that the right of procreative choice is anchored in the text of the California Constitution's right to privacy. The right to privacy was not in the text of the constitution when, in People $v$. Belous, ${ }^{133}$ the California Supreme Court first announced that a right of procreative choice followed from the right to privacy. Thus, the Belous court was unable to point to any express textual support for a constitutional right of privacy and imstead rehed on earlier judicial acknowledgments of a right to privacy in matters relating to marriage, family, and sex. ${ }^{134}$ Several years after Belous, however, the right of privacy gamed exphicit constitutional status in California in a 1972 amendment passed by the voters. ${ }^{135}$

The scope of this privacy amendment has been sketched in several supreme court decisions. ${ }^{136}$ The thrusi of the privacy right, as set out in the ballot materials, was protection of the individual from the inforniation collection activities of large private organizations and government. ${ }^{137}$ Initially it appeared that the court might limit the scope of the

132. See People v. Belous, 71 Cal. 2d 954, 967-69, 458 P.2d 194, 202-03, 80 Cal. Rptr. 354, 362-63 (1969).

133. 71 Cal. 2d 954, 458 P.2d 194, 80 Cal. Rptr. 354 (1969).

134. See supra note 32 and accompanying text.

135. The right of privacy was added to the other malienable rights enumerated in CAL. ConsT. art. 1, \&1. Another amendment reworded the section in 1974 so that it now reads: "All people are by nature free and independent and lave inalienable rights. Among these are enjoying and defending life and liberty, acquiring, possessing and protecting property, and pursuing and obtaining safety, happiness and privacy."

136. Before $C D R R$, lowever, the court liad not addressed the question of low the privacy constitutional amendment affected the right of procreative choice. Although Bowland v. Municipal Court, 18 Cal. 3d 479, 556 P.2d 1081, 134 Cal. Rptr. 630 (1976), implicated the right of procreative clroice, the court did not discuss the possible relevance of the privacy amendment.

137. The argument in favor of the privacy amendment read in part:

The proliferation of government snooping and data collecting is threatening to destroy our traditional freedoms. Government agencies seem to be competing to compile the 
amendment to these concerns. In White v. Davis, ${ }^{138}$ for example, the court identified the "moving force" behind the privacy amendment as "the accelerating encroachment on personal freedoin and security caused by increased surveillance and data collection activity in contemporary society." 139 Then, in People v. Privitera, ${ }^{140}$ the court again read the privacy annendment narrowly, finding no support in the privacy ballot materials for an asserted freedom to use an unproven drug such as laetrile. One year before $C D R R$, however, in City of Santa Barbara v. Adamson, ${ }^{141}$ the court took a different tack and read the amendinent more expansively to protect private decisions outside the information collection and dissemination areas. The Adamson court held that the right of privacy extended to associational choices and invahidated a city zoning ordinance that limited the number of unrelated persons who could live together in a single dwelling. ${ }^{142}$

Relying on the expansive scope of the privacy right recognized in Adamson, the CDRR court held that "the protection afforded the woman's right of procreative choice [is] an aspect of the right of privacy under the exphicit provisions of our Constitution." ${ }^{143}$ By anchoring the

most extensive sets of dossiers of American citizens. Computerization of records makes it possible to create "cradle-to-grave" profiles on every American.

At present there are no effective restraints on the information activities of government and business. This amendment creates a legal and enforceable right of privacy for every Californian.

The right of privacy is the right to be left alone. It is a fundamental and compelling interest. It protects our homes, our families, our thoughts, our emotions, our expressions, our personalities, our freedom of communion, and our freedom to associate with the people we choose. It prevents government and busimess interests from collecting and stockpiling unnecessary information about us and from misusing information gathered for one purpose in order to serve other purposes or to embarass us.

Ballot Pamplet, Proposed Amendments to Califormia Constitution with Arguments to Voters, General Election, Nov. 7, 1972, at 26-27 (emphasis in origimal).

138. 13 Cal. 3d 757, 533 P.2d 222, 120 Cal. Rptr. 94 (1975) (Tobrimer, J., for a unanimous court).

139. Id. at 773-74, 533 P.2d at 233, 120 Cal. Rptr. at 105 (footnote omitted).

140. 23 Cal. 3d 697, 709-10, 591 P.2d 919, 926, 153 Cal. Rptr. 431, 438, cert. denied, 444 U.S. 949 (1979). Cf. id. at 726-29, 591 P.2d at 937-39, 153 Cal. Rptr. at 448-51 (Bird, C.J., dissenting) (criticizing the narrow scope given to the privacy amendment); id. at 740-41, $591 \mathrm{P.2d}$ at 946,153 Cal. Rptr. at 458 (Newman, J. dissenting) (same).

141. 27 Cal. 3d 123, 610 P.2d 436, 164 Cal. Rptr. 539 (1980).

142. The court impliedly lield that the ordinance infringed on the constitutional right to privacy. See Note, City of Santa Barbara v. Adamson: An Associational Right of Privacy and the End of Family Zones, 69 CALIF. L. REv. 1052 (1981).

143. $29 \mathrm{Cal} .3 \mathrm{~d}$ at $281,625 \mathrm{P} .2 \mathrm{~d}$ at $796,172 \mathrm{Cal}$. Rptr. at 883 . Chief Justice Bird agreed. Id. at 291-92, 625 P.2d at 803-04, 172 Cal. Rptr. at 890-91 (Bird, C.J., concurring). She pointed out that the amendment's proponents had urged in the ballot materials that " $[t]$ his simple amendment will extend various court decisions on privacy to insure protection of our basic rights." Id. at 291, 625 P.2d at 803, 172 Cal. Rptr. at 890 (Bird, C.J., concurring) (quoting Ballot Phamphlet, Proposed Amendments to Califorma Constitution with Argunents to Voters, General Election, Nov. 7, 1972, at 28). Since Belous predated the amendment and grounded the right of procreative choice in a right of privacy or liberty, see supra text accompanying notes 31-32, the ballot proponents likely beheved that procreative choice was within the intended scope of the privacy amend- 
right of procreative choice in the California privacy amendmont, the court was able to conclude that it was not bound by federal precedents defining the scope of the privacy right under the federal Constitution. ${ }^{144}$ The court also noted that in Adamson it had recognized that the right of privacy in California is broader than the analogous federal right because of its explicit constitutional status. ${ }^{145}$ Thus, the court was free to disregard the outcomes of Maher v. Roe $e^{146}$ and Harris v. Mc$R a e^{147}$ and reach its second holding: that the right of procreative clioice requires greater protection against state interference under the Califormia Constitution than under the federal Constitution. ${ }^{148}$

Fimally, the court held that under the California Constitution, the state's interest in protectimg a nonviable fetus is subordinate to the woman's procreative right. ${ }^{149}$ The court reasoned that the heightened protection accorded the procreative choice in California meant that the state conld only interfere with the right if it could assert a compelling state interest. Simce Roe v. Wade ${ }^{150}$ leld that under the federal Constitution the protection of a nonviable fetus is not a compelling state interest, ${ }^{151}$ and simce the California right of procreative choice must be "at least as broad" as the federal right announced in Roe, ${ }^{152}$ the state's interest in protectimg a nonviable fetus was not a compelling state interest and could not justify interfering with a woinan's right of procreative choice.

Together, these three holdings-that the right of procreative choice is anchored in the California Constitution's privacy amendinent, that the right of procreative choice receives greater protection under the California Constitution than under the federal Constitution, and that the state interest in protecting a nonviable fetus is not sufficiently compelling to justify interfering with a woman's procreative choice-

ment. It is more doubtful, however, that the voters were aware that the privacy amendment would strengthen the right of procreative choice. Given the strong anti-abortion sentiments of some California residents, it is unlikely the privacy amendment would have passed with so little controversy had the voters realized it would be used to limit the state's authority to restrict or disfavor abortions.

144. $29 \mathrm{Cal}$. 3d at 263,625 P.2d at 784, 172 Cal. Rptr. at 871 ; id. at 294, 625 P.2d at 805,172 Cal. Rptr. at 892 (Bird, C.J., concurring).

145. $27 \mathrm{Cal}$. 3d at 130 n.3, 610 P.2d at 440 n.3, 164 Cal. Rptr. at 543 n.3. This statement was supported by no analysis and by two citations, neither of which tended to substantiate the court's assertion. See Note, supra note 142, at 1065-66.

146. 432 U.S. 464 (1977).

147. 448 U.S. 297 (1980).

148. $29 \mathrm{Cal}$. 3d at $284,625 \mathrm{P} .2 \mathrm{~d}$ at $798,172 \mathrm{Cal}$. Rptr. at 885 (by implication); id. at 294,625 P.2d at 805, 172 Cal. Rptr. at 892 (Bird, C.J., concurring) ("Our state Constitution mandates a stricter standard than that used by the Supreme Court . . . .")

149. Id. at 281, 625 P.2d at 796, 172 Cal. Rptr. at 883.

150. 410 U.S. 113 (1973).

151. Id. at 163 .

152. $29 \mathrm{Cal}$. 3d at 281, $625 \mathrm{P} .2 \mathrm{~d}$ at 796,172 Cal. Rptr. at 883. 
greatly strengthen the protection given in California to the right of procreative choice. This heightened protection evidences the $C D R R$ court's behef that the right has special importance.

This behef is also reflected in the strongly worded dicta in several passages of the court's opinion. First, $C D R R$ recited additional interests of the wornan that the right protects. Previous decisions had said that the right implicates the woman's "fundamental interest in the preservation of her personal health"153 and "her right to decide whether to parent a child."154 To that list of protected interests, $C D R R$ added that the procreative right protected the woman's "ability to retain personal control over her own body" and "her control of her social role and personal destiny."155 Arguably, the strength of a right is directly related to the number and importance of the interests the right protects. Thus, when the court enumerates additional interests that are as fundamental as a woman's control over her body and her social role, the court announces an imtention to strengthen the overall right of procreative choice.

The plurality opinion made another significant comment on the right of procreative choice. It concluded that the woman's rights to life and procreative choice are "among the most intimate and fundamental of all constitutional rights."156 By placing the right of procreative choice among the uppermost tier of fundamental rights, the court implied that the right of procreative choice was due a special measure of constitutional protection.

The plurality's ranking approach to fundamental riglts was rejected by Chief Justice Bird's concurring opinion, however, and thus was not supported by a majority of the court. In discussing the appropriate standard of review, Bird criticized the idea of balancing degrees of burden and fundamentalness. ${ }^{157}$ Her concern was that ranking would lead to a weakening of some constitutional rights, because future courts could permit inipairment of the lesser rights on a showing of less than a compelling state interest. ${ }^{158}$ Despite her reluctance to rank the

153. Id. at 274, 625 P.2d at 792, 172 Cal. Rptr. at 879 (citing Belous, 71 Cal. 2d at 963, 458 P.2d at 199-200, 80 Cal Rptr. at 359-60, and Ballard v. Anderson, 4 Cal. 3d at 879, 484 P.2d at 1349, 95 Cal. Rptr. at 5).

154. $29 \mathrm{Cal}$. 3d at 275, 625 P.2d at 792, $172 \mathrm{Cal}$. Rptr. at 879 (citing Belous, $71 \mathrm{Cal} .2 \mathrm{~d}$ at 963 , 458 P.2d at 199, 80 Cal. Rptr. at 359).

155. 29 Cal. 3d at 274-75, 625 P.2d at 792, 172 Cal. Rptr. at 879.

156. Id. at 275, 625 P.2d at 793, $172 \mathrm{Cal}$. Rptr. at 880 . In a similar vein, the court said that "ouly the most compelling of state interests could possibly satisfy" the Bagley test of manifestly outweighing the impairment of the right of procreative choice. Id. at 276, 625 P.2d at 793, 172 Cal. Rptr. at 880 (emphasis added).

157. Id. at 289 n.2, 625 P.2d at 801 n.2, 172 Cal. Rptr. at 888 n.2 (Bird, C.J., concurring).

158. Id. (Bird, C.J., concurring) (citing Hawkins v. Superior Court, 22 Cal. 3d 584, 607-10, 586 P.2d 916, 931-33, 150 Cal. Rptr. 435, 450-52 (1978) (Bird, C.J., concurring)). As a matter of 
right of procreative choice above other constitutional rights, however, Chief Justice Bird did acknowledge that the California Constitution, cases, and laws evidenced the state's "special concern" for privacy. ${ }^{159}$ Thus, even though a majority of the court did not support an approach that would rank the right of procreative choice above other constitutional rights, a majority did agree that the right is a very important one, deserving a high standard of protection against state interference.

Although the holdings and dicta in the $C D R R$ opinion emphasized the special importance of the right of procreative choice under the Cahfornia Constitution, the court stopped short of announcing a requirement of strict governmental neutrality towards the expressions of the procreative right. ${ }^{160}$ As a result, the court's holding permits state actions that favor spccific exercises of the right of procreative choice. For example, $C D R R$ does not prohibit selective funding outside the context of a general benefit program. In this respect $C D R R$ does not go as far toward restricting discriminatory selective funding of procreative choices as other court decisions do with respect to first ainendinent rights. Part $\mathrm{C}$ argues that a neutrality requirement should be recognized with respect to the right of procreative choice, in part because the right is closely analogous to first amendment rights. First, however, Part $B$ briefly discusses the first amendment neutrality idea and the resulting special line of unconstitutional condition cases that strike down selective funding.

\section{B. Selective Funding in the First Amendment Context}

In contrast to the penalty analysis generally used in evaluating the constitutionality of conditioned spending prograins, ${ }^{161}$ selective funding has been struck down im first amendment cases witlout regard to

constitutional principle, the Bird view that all constitutional rights are of equal importance is surely wrong. For example, the first amendment is generally understood to enjoy a preferred position among constitutional rights. See, e.g., J. NowAK, R. RoTUNDA, \& J. Youna, HANDBook ON Constitutional LAw 718-20 (1978). The state is required to be neutral with regard to certain first amendment rights but not with most other rights. See Tribe, supra note 93 , at 290 . In balancing the burden on the right with the asserted state interest, courts routmely recognize that some rights are more fundamental than others. See, e.g., CDRR, 29 Cal. 3d at 273, 625 P.2d at 791, 172 Cal. Rptr. at 878 (' $[\mathrm{I}] \mathrm{n}$ undertaking this 'weighing' or 'balancing' process . . . the court inust carefully evaluate the importance of the constitutional right at stake . . ..") An approach that treats all rights as equally fundamental either represeuts a massive bootstrapping of some rights or implies a lesser protection for other rights now treated as more fundamental. In either case, the Bird approach represents a less measured approach to what should be a sensitive weighing process.

159. $29 \mathrm{Cal} .3 \mathrm{~d}$ at 293,625 P.2d at $804,172 \mathrm{Cal}$. Rptr. at 891.

160. The Bird concurring opirion observed that some courts liad recognized a neutrality principle, but the opinion did not endorse the idea. 29 Cal. 3d at 288, 625 P.2d at 801, 172 Cal. Rptr. at 888 (Bird, C.J., concurring).

161. See supra text accompanying notes 93-101. 
whether the funding imposes a penalty on the exercise of first amendment rights. A different principle-that of neutrahity ${ }^{162}$-is apphed to these cases because of the special importance of the first amendment.

The first amendment occupies a special position in the constitutional scheme. ${ }^{163}$ Because of its special importance, the courts generally give greater scrutimy to possible infringments of first amendment rights than they do to other constitutional rights. Very minor acts of favoritism may be struck down under this strict standard of review.

In many situations, this greater scrutiny has led to the rule that the government must be neutral with respect to first amendment protected choices. Thus, a fundamental principle of the first amendment is that government regulation must be neutral with respect to the content of protected speech. ${ }^{164}$ Regulations that are not neutral because they selectively fund certam speech content are struck down, even if the regulations do no more than provide an imdirect subsidy to certain speech content, such as by selectively granting access to a forum. ${ }^{165}$ Similarly, another fundamental principle of the first amendment is that the government must be neutral so as not to support the estabhshment of religion nor to prevent its free exercise. ${ }^{166}$ In sum, stricter scrutimy im the first amendment context often results in a requirement that the government be neutral with respect to the exercise of the right.

Because distimctions developed in first amendment cases do not necessarily apply to other constitutional rights, the neutrality principle has not generally been applied outside the first amendment context. ${ }^{167}$

162. The neutrality principle advocated here is similar to the equality principle that has been identified as central to the first amendment. See Karst, Equality as a Central Principle in the First Amendment, 43 U. CHI. L. REv. 20 (1975).

163. See J. NowaK, R. Rotunda \& J. Young, supra note 158, at 718-20.

The California Constitution contains a provision protecting free speech analogous to the language of the first amendment. See CAL. ConST. art. I, $\S 9$ ("[N]o law shall be passed to restrain or abridge the liberty of speech or of the press.") California courts have recognized a preferred position for this right of free expression in Califorina's constitutional scheme. See, e.g., Weaver v. Jordan, 64 Cal. 2d 235, 241, 411 P.2d 289, 293, 49 Cal. Rptr. 537, 541 (1966).

164. See, e.g., Chicago Police Dep't v. Mosley, 408 U.S. 92, 95 (1972) ("[A]bove all else, the First Amendment means that government has no power to restrict expression because of its message, its ideas, its subject matter, or its content.").

165. Many public forum cases, for example, involve a simple failure to fund. When restrictions are placed on public forums denying the use of the forum based on the content of speech, the state is funding some content and failing to subsidize other content. This is not a penalty, there is not a loss of otherwise available benefits, just a failure to fund certain speecl. Nevertheless, such content restrictions are struck down. See, e.g., Fowler v. Rhode Island, 345 U.S. 67 (1953); Niemotko v. Maryland, 340 U.S. 268 (1951).

166. J. NowAK, R. ROTUNDA, \& J. YouNG, supra note 158, at 849. A "natural antagonisn" between the free exercise and establishment clauses is one source of the neutrality requirement with respect to freedom of religion. Id.

167. See, e.g., C. Black, The People and the Court 217-21 (1960); J. NowaK, R. RoTUNDA \& J. Young, supra note 158, at 718-20; M. SHAPIRO, FREEDOM OF SPEECH 108-21 (1966); McKay, The Prefercnce for Freedom, 34 N.Y.U. L. REv. 1182 (1959). 
Thus, as the Part III discussion of the disruptive effect of the selective funding principle illustrated, the government is not generally required to be neutral with respect to the exercise of constitutional rights. ${ }^{168}$ For example, although there is a fundamental right to marry and divorce, the government may favor married persons over smgle persons in some of its programs. ${ }^{169}$ Similarly, although there is a constitutional right to attend either a public or private school, selective funding limited to public schools has been upheld. ${ }^{170}$

A requirement of neutrality leads to a different unconstitutional conditions analysis of selective funding. As explamed in Part II, the unconstitutional conditions doctrine stands for the proposition that if the government may not directly burden the exercise of a right, it cannot do so indirectly by means of conditioned benefits. ${ }^{171}$ If selective funding is struck down when analyzed as a direct infringement, it is similarly unconstitutional when analyzed as an indirect infringement under the unconstitutional conditions doctrine. This is why unconstitutional conditions analysis is different in the first amendinent context than it is with respect to other rights.

Thus, a neutrality requirement under the first amendinent usually requires that selective funding be struck down. The following section argues that the $C D R R$ court should have applied the neutrality principle to the right of procreative choice. This would have required that the court strictly scrutinize the $C D R R$ selective funding scheme, just as it now strictly scrutinizes selective funding im the first amendinent cases.

\section{B. A Proposed Neutrality Principle}

\section{The Case for the Neutrality Principle}

The court should require the state to act neutrally with regard to the expressions of the right of procreative choice for two reasons. First, the procreative right is a profoundly important one under the California Constitution, analogous in importance to the first annendment. Second, the right of procreative choice originated in part im the first amendincnt, where a neutrality principle is generally recognized. Each of these reasons is analyzed in detail below.

The first reason that a neutrality principle should be recognized is that in California the right of procreative choice is specially important, analogous in importance to the first amendment right of free expres-

168. See supra text accompanying notes 109-16.

169. E.g., the special tax schedule for married couples. See supra note 111.

170. See, eg., Pierce v. Society of Sisters, 268 U.S. 510 (1925). Pierce is discusscd supra in text accompanying notes 107-08.

171. See supra text accompanying notes $43-44$. 
sion. ${ }^{172}$ This special importance of the procreative right in the California constitutional scheine was emphasized in the $C D R R$ opinion. ${ }^{173}$ One reason for this importance is that the potential consequences to the woman from the procreative decision are so far-reaching. Her health is always affected and may be threatened if she is unable to implement her procreative choice. ${ }^{174}$ Moreover, the autonomy of her body from outside influence and control is threatened when her procreative choice is abridged. Forcing a woman to bear a child she does not want is equivalent to forcing her to undergo a serious and longterm medical procedure she does not want. The same rights of privacy and bodily autonony are imvolved. Finally, her control over her social role and personal destiny is involved. ${ }^{175}$ The responsibilities of a child may fundamentally shape the rest of her life; the arrival of an unwanted child can have a profound negative effect on the vocational and social options available to a woman.

The unique characteristics of the procreative decisionmaking situation also make the right specially important. The decision of whether or not to bear a child involves mutually exclusive choices. In making her decision, the wonian necessarily rejects the other alternative. Moreover, the decision must be made in a short period of time. A pregnant woman at the most has only a sniall nuniber of months to decide whether or not to bear a child. Once the decision is inade, and the woman has an abortion or gives birth to a child, the decision is final and irreversible. In sum, a woman contemplating abortion inust nuake a quick and perhaps severely pressured decision that may fundamentally affect her life. These factors distinguish the procreative choice fron other constitutionally protected choices. ${ }^{176}$ In this difficult situa-

172. This Note's neutrality analysis is based in part on the fact that the California Constitution accords greater protection to the right of procreative choice than the federal Constitution. See supra notes 143-48 and accompanying text. Thus, even if the federal procreative right is not of analogous importance to the first amendment, see Maher v. Roe, 432 U.S. 464, 474 n.8 (distinguishing the analysis of abortion funding from that used in the first amendment case of Sherbert $v$. Verner, 374 U.S. 398 (1963)), the California Constitution may accord it an analogous importance. Thus, neutrality may be appropriate under the California Constitution even if it is not required under the federal Constitution.

173. See supra text accompanying notes 132-60.

174. CDRR, 29 Cal. 3 d at 272 n.21, 625 P.2d at 790-91 n.21, 172 Cal. Rptr. at 877-78 n.21.

175. See Karst, The Supreme Court, 1976 Term-Forward: Equal Citizenship Under the Fourteenth Amendment, 91 HARv. L. REv. 1, 57-58 (1977).

176. Justice Powell noted "the unique nature of the abortion decision." Bellotti v. Baird, 443 U.S. 622, 642 (1979). See Tribe, Constitutionally Protected Areas, in J. ChOPER, Y. KAMISAR, \& L. Tribe, The Supreme Court, Trends and Developments: 1978-1979, at 303, 307 (1979) [hereinafter cited as TRENDS AND DEVELOPMENTS, 1978-1979] ("Ever since 1973 the Court has treated abortion as sui generis - very special, quite separate, not really analogous to its treatment of other substantive issues.") 
tion, the state should not weight the woman's choice, but should maimtain a neutral stance.

These important and unique features of the procreative right make it analogous in importance to the first ainendment. The first amendment is specially important because it is understood as essential to the process of constitutional democracy. ${ }^{177}$ Analogously, the right of procreative choice, for the special and unique reasons given, should be viewed as an essential element of the imdividual freedom and self-determination that underlie our constitutional scheme. Looked at in this way, the intrusion on a woman's decision whether or not to bear a child is just as great a constitutional violation as an intrusion by the state on political speech. Because of the similar importance of the rights, the courts should give them similar protection. Thus, it is appropriate to extend the first amendment neutrality principle to the right of procreative clioice.

A second reason that a neutrality principle should be recognized is that the procreative right is properly understood as being, at least in part, a first amendment riglit. The origins of the right of procreative choice and the right of privacy trace in part to the first amendment. ${ }^{178}$ For example, in announcing a right of procreative choice in People $v$. Belous, ${ }^{179}$ the California Supreme Court cited several first amendment cases as sources for the right. ${ }^{180}$ Moreover, under some theories of the first amendment both privacy ${ }^{181}$ and procreative choice ${ }^{182}$ are seen as directly protected by the first amendment. This is because some authorities understand the first amendment to protect conduct fostering self fulfillment and self determination. ${ }^{183}$ The procreative right imph-

177. See supra text accompanying notes 163-64.

178. The constitutional right to privacy recognized in Griswold v. Connecticut, 381 U.S. 479 (1965), was traced in part to the penumbra of the first amendment. Id. at 482-83.

179. 71 Cal. 2d 954, 458 P.2d 194, 80 Cal. Rptr. 354 (1969).

180. Id. at 963,458 P.2d at 199, 80 Cal. Rptr. at 359. Belous held that the right followed from Griswold, which is partially a first amendment decision, see supra note 178, and froin two other cases that the Griswold court identified as first amendment cases, Pierce v. Society of Sisters, 268 U.S. 510 (1925), and Meyer v. Nebraska, 262 U.S. 390 (1923). See also Bowland v. Municipal Court, 18 Cal. 3d 479, 494, 556 P.2d 1081, 1089, 134 Cal. Rptr. 630, 638 (1976) (constitutional rights to privacy and procreative choice derive in part from the first amendment); T. EMERSON, THE SySTEM OF FreedoM OF EXPRESSION 547 (1970).

181. See Stanley v. Georgia, 394 U.S. 557, 564 (1969) ("It is now well established that the [first amendment] protects the right to receive information and ideas . . . . [I]n the context of this case . . . that right takes on an added dimension. For also fundamental is the right to be free, except in very limited circumstances, from unwanted governmental intrusions into one's privacy."); King v. California Uneınployınent Ins. Appeals Bd., 25 Cal. App. 3d 199, 205-06, 101 Cal. Rptr. 660, 664 (1st Dist. 1972) (wearing of beard protected under first amendinent).

182. Dixon, The "New" Substantative Due Process and the Democratic Ethic: A Prolegomenon, 1976 B.Y.U. L. REV. 43, 85.

183. For example, Professor Baker advocates a "liberty model" of the first amendment that protects certain conduct "foster[ing] individual self-realization and self-determination." Baker, 
cates these same values, as the $C D R R$ court strongly emphasized. ${ }^{184}$ Thus, because procreative choice bears this close connection to the first amendment, the neutrality principle should be applied to the procreative right.

In sum, there are sound constitutional reasons for recognizing a neutrality requirement with respect to the right of procreative choice. These reasons inhere in the relationship of the procreative right to the first amendment and in the special importance of the right. This neutrality principle would lead to the same result as reached in $C D R R$, smce restrictions on abortion funding but not childbirtl funding are a nonneutral state act. Thus, neutrality would require that selective funding of procreative choice be struck down, just as it requires that selective funding of favored speech or religion be struck down. ${ }^{185}$

\section{Application of the Neutrality Principle}

The neutrality principle requires strict scrutimy of state actions that selectively favor one expression of the right of procreative choice over another. The principle would be applied in a manner similar to other constitutional principles. A court would undertake a balancing analysis, upholding nonneutral state actions that are justified by a sufficiently compelling state interest and striking down those that do not serve compelling state interests. ${ }^{186}$

To evaluate whether the state in fact acted neutrally, the court could employ the type of equal protection analysis now used to evaluate state actions that have a disproportionate racial impact. ${ }^{187}$ Where the non-neutral act in the form of a direct benefit or burden appears on the face of the statute, as for example witl tlie selective funding of childbirth or the subsidy for only intraracial marriages, the statute is strictly scrutinized and struck down unless the state advances a sufficiently compelling state interest. Where the statute does not directly discriminate on its face, as for example witl the funding for adoption

Scope of the First Amendment Freedom of Speech, 25 U.C.L.A. L. Rev. 964, 966 (1978). Professor Enerson identifies individual self fulfillment as one of the four categories of values underlying the system of freedom of expression. Enerson, First Amendment Doctrine and the Burger Court, 68 CALIF. L. Rev. 422, 423 (1980).

184. See supra notes $154-55$ and accompanying text.

185. At least one state has adopted a neutrahty requirement for procreative choice. The Massachusetts decision striking down abortion funding restrictions was predicated precisely on a neutrahty conception: "the limitation on State action which is imposed by the fundamental right of privacy in Roe v. Wade, . . . is one of neutrality." Moe v. Secretary of Admin., - Mass. -, 417 N.E.2d 387, 400 (1981) (einphasis added).

186. E.g., Zablocki v. Redhail, 434 U.S. 374 (1978); Choper, Fundamental Rights, in TRENDS AND DEVELOPMENTS, 1978-1979, supra note 176, at 255, 262-63.

187. For an extensive discussion of this type of analysis, see Perry, The Disproportionate Impact Theory of Racial Discrimination, 125 U. PA. L. REv. 540 (1977). 
services or qualifications tests for civil service jobs, but the statute has a discriminatory.effect, then the court examines the legislative motivation. ${ }^{188}$ The statute is strictly scrutinized only if the evidence shows that a "but for" cause of the state's motivation was to discriminate on the basis of the constitutional right. ${ }^{189}$

This type of analysis avoids the potential difficulty that the neutrality principle could threaten many government programs that might indirectly favor a procreative option. For example, adoption programs or subsidies for pregnant mothers may indirectly favor childbirth over abortion in that such programs could influence a pregnant woinan's decision as to whether or not to bear a child. Such indirect effects would be struck down under the neutrality principle suggested here, however, only if they had both the purpose and the effect of weighting the woman's procreative choice. ${ }^{190}$ Thus, as long as the state is not seeking to burden the woman's choice, it is free to pursue legitimate interests, even if they have an indirect effect on procreative choice.

\section{CONCLUSION}

In Committee to Defend Reproductive Rights v. Myers, the California Supreine Court faced a constitutional attack on abortion funding restrictions placed on a general medical services program for the poor. The court analyzed the funding restrictions as an unconstitutional condition. The holding was based on the principle that the court would strictly scrutinize the selective funding of a constitutional right in the

188. Historically, courts have not generally considered legislative motivation in constitutional adjudication. See, eg., Umited States v. O'Brien, 391 U.S. 367, 383-84 (1968). In the early 1970's, two influential articles, Brest, Palmer v. Thompson: An Approach to the Problems of Unconstitutional Legislative Motive, 1971 Sur. CT. REv. 95, and Ely, Legislative and Administrative Motivation in Constitutional Law, 79 YALE L.J. 1205 (1970), argued that the courts should consider legislative motive under certain circumstances. Since then, the United States Supreme Court has handed down several important decisions based on the presence of unconstitutional legislative motivation. See, e.g., Washington v. Davis, 426 U.S. 229 (1976).

189. See Village of Arlington Heights v. Metropolitan Hous. Dev. Corp., 429 U.S. 252 (1977).

190. This purpose and effect analysis can also be illustrated by examining the income tax exemptions for dependent children. These exemptions are not facially discriminatory, since they do not directly support either abortion or childbirth. They do indirectly favor childbirth, however. The effect of these exemptions is to inake children less of an economic burden than they would otherwise be, and, thus, such tax exemptions do weight the woman's procreative choice. Since the effect element is present, the issue is whether the purpose of the dependent tax exemptions is to influence the procreative choice. Under the analysis proposed here, the party claiming that the government has been discriminatory must show that a but for purpose of the tax exemptions is to burden the woman's choice. Inasmuch as the stated purpose of the exemptions was to account in some measure for the expenses of providing for a dependent, and imasnuch as the tax exemptions were passed at a time when abortion was generally illegal anyway, it is unlikely that it can be shown that a but for purpose of enacting the exeinptions was to discourage abortion in favor of childbirth. Thus, the neutrality principle suggested here would not invalidate tax exemptions for dependent children. 
context of a general benefit program for the poor. The abortion funding restrictions did not survive judicial scrutiny and were struck down.

This Note argues that the court reached the right result but that its analysis was flawed. Although it claimed to be restating precedent, the court announced a significant new constitutional rule against the selective funding of constitutional rights. This rule excessively restricts the power of majoritarian institutions, and, by being restricted to general benefit prograins, weakens the force of the arguments made on the rule's behalf.

The court should have struck down the abortion funding restrictions on the ground that the right of procreative choice is so important that the government is limited to a role of neutrality. CDRR did strengthen the California right of procreative choice, extending its reach beyond the analogous federal right and pronouncing it as one of the nost fundamental of constitutional rights. But the court did not go far enough in protecting the right from discriminatory state action. This Note argues that the court should have required the state to act neutrally with respect to the expressions of the right of procreative choice, just as it does with first amendment rights. This neutrahty principle is supportcd by the special nature of the procreative right and the close connection of the procreative right to the first amendment. The court therefore should have struck down the abortion funding restrictions as a violation of the neutrality requirement.

Charles W. Sherman*

- B.A. 1968, M.S. 1971, Florida State University; third-year student, Boalt Hall School of Law, University of California, Berkeley. 